\title{
The Impact of Local Climate Change on Radial Picea abies Growth: A Case Study in Natural Mountain Spruce Stand and Low-Lying Spruce Monoculture
}

\author{
Vladimír Šagát ${ }^{1, *}$, Ivan Ružek ${ }^{1}$, Karel Šilhán ${ }^{2}$ and Pavel Beracko ${ }^{3}$ \\ 1 Department of Physical Geography and Geoinformatics, Faculty of Natural Sciences, Comenius University, \\ Ilkovičova 6, 84215 Bratislava, Slovakia; ivan.ruzek@uniba.sk \\ 2 Department of Physical Geography and Geoecology, Faculty of Natural Sciences, University of Ostrava, \\ Chittussiho 10, 71000 Ostrava, Czech Republic; karel.silhan@osu.cz \\ 3 Department of Ecology, Faculty of Natural Sciences, Comenius University, Ilkovičova 6, 84215 Bratislava, \\ Slovakia; pavel.beracko@uniba.sk \\ * Correspondence: sagat13@uniba.sk
}

Citation: Šagát, V.; Ružek, I.; Šilhán, K.; Beracko, P. The Impact of Local Climate Change on Radial Picea abies Growth: A Case Study in Natural Mountain Spruce Stand and Low-Lying Spruce Monoculture. Forests 2021, 12, 1118. https:// doi.org/10.3390/f12081118

Academic Editor: Bao Yang

Received: 9 July 2021

Accepted: 17 August 2021

Published: 21 August 2021

Publisher's Note: MDPI stays neutral with regard to jurisdictional claims in published maps and institutional affiliations.

Copyright: (C) 2021 by the authors. Licensee MDPI, Basel, Switzerland. This article is an open access article distributed under the terms and conditions of the Creative Commons Attribution (CC BY) license (https:/ / creativecommons.org/licenses/by/ $4.0 /)$.

\begin{abstract}
Picea abies L. Karst is undeniably one of the most important tree species growing in Slovakia. In addition to natural mountain spruce forests, monocultures planted in lower areas are also quite common. In this article, we analyze the climate-growth response differences between these two types of spruce stands in the context of local climate change consequences. The study area representing natural mountain spruce forests is located under Osobitá Mt. (Tatra Mountains, Slovakia), while the analyzed low-lying planted monoculture is situated near Biely kríž (Malé Karpaty Mountains, Slovakia). Temporal variation of the dendroclimatological relationships was expressed by the running Spearman correlation coefficient during the observed period 1961-2018. The results showed crucial differences in the dendroclimatological relationships between the selected study areas. For the natural mountain spruce stand, consistent, weak, and positive correlations to the temperature variables were typical, with negative relationships to precipitation during the growing season. In this case, the negative impact of a recent temperature rise was limited. In contrast, the monoculture reacted to the temperature variation during the growing season with fluctuations, while in the case of precipitation, almost no dependence was found. Such incoherency may be a consequence of worsened health conditions, as well as insufficient resiliency to climate-driven stress. The importance of this paper is in its wide applicability, mainly in forestry.
\end{abstract}

Keywords: Picea abies; dendroclimatology; running correlation; climate change; Slovakia

\section{Introduction}

At present, a notable amount of studies are being completed in order to understand the spatial and temporal impact of ongoing climate change since it undeniably influences all land components. Dendroclimatology focuses on the relationship between climate trends and radial tree growth. It is a scientific field that contributes significantly to the growing knowledge related to climate change.

The Norway spruce (Picea abies L. Karst) is considered to be the most important tree species in Slovakia, both ecologically and economically. The area of its natural distribution is spread out on mountain slopes with a minimum altitude of approximately $1100 \mathrm{~m}$. However, there is also an important issue concerning the low-situated non-natural spruce monocultures. In the past, they were widely planted across the entire region of Slovakia. Unfortunately, there is sufficient evidence that these stands have suffered from worsened health conditions and are less resilient to a variety of natural disturbances when compared to natural mountain spruce stands [1].

Picea abies appears to be the least resilient common tree species in Slovakia in terms of the amplified negative influences of global climate change [1]. The issues of replacing 
monocultures with more resilient species, a conservative approach in protected areas [2], as well as general knowledge of the climate change impacts on the biosphere are therefore the main reasons why it is an appropriate subject of interest for many dendroclimatological studies.

When analyzing the climate change impacts on the radial increments of Picea abies, it is crucial to note that there is a wide range of other influences, either abiotic, biotic or anthropogenic, all of which affect the way a tree ring grows. In the case of studying one particular impact, all the others need to be minimalized or eliminated so that they do not distort the final results [3]. The investigated impact is considered to be a signal, whereas all the other influences are filtered as a noise [4].

Over the last few years, a variety of dendroclimatological studies have been carried out in Central Europe. Quite often, they have focused on the statistically expressible relationship between the tree ring width (TRW) standard chronology and the time series of particular climate variables for a specific period of time. Treml et al. [5] analyzed the natural spruce stands in the Sudetes Mountains. Ponocná et al. [6] focused on pollution and climate change as the main drivers of the recent decoupling of tree ring growth from the observed temperature rise in the natural spruce forests in the Sudetes and Slovak Carpathians. Vitali et al. [7] studied the radial growth reaction to drought in the non-natural stands of the Black Forest. Cienciala et al. [8] performed extensive research on the environmental drivers of TRW growth in the non-natural forests of the Czech Republic. Altman et al. [9] used the same samples to examine the climate growth relationships affected by several geographical, soil, and biotic variables. Sedmáková et al. [10] researched the tree ring growth responses on selected temperature and precipitation variables with changing altitude in the context of climate change in several forest vegetation zones in Pol'ana, Slovakia. Bošel'a et al. [11] looked through the relationships between the recent health decline and climate change influence in the Beskids Mountains, in both natural and non-natural stands. Parobeková et al. [12] focused on the tree increments' response to climate change consequences in the natural spruce forests of the Low Tatras. Buras et al. [13] analyzed divergent spruce growth on Babia Góra Mountain and its possible drivers, while Kaczka et al. [14] inspected climate-growth relationships in the timberline ecotone at the same location. More similar studies have been published, of course [15-22].

With regard to the aforementioned papers, as well as in the framework of the recent paradigm, we address the following hypotheses:

1. The strength and nature of dendroclimatic relationships differ in the natural mountain spruce stand, as well as in those planted outside the area of natural spruce distribution. In the mountain stand, a temperature-driven signal takes place, while the low-situated monoculture is characterized by a moisture-driven signal.

2. P. abies growth responses to the consequences of climate change (namely, temperature rise and changes in precipitation distribution) are more consistent in the natural mountain stand when compared to the low-situated monoculture.

In order to verify these hypotheses, we intend to statistically express the relationships between RWI (Ring Width Index) chronologies and the time series of selected temperature and precipitation variables. Two study areas will be compared: a natural mountain spruce forest and a low-lying monoculture. For expression of the temporal variability of dendroclimatic relationships from 1961 to 2018, 20-year running correlations will be used.

\section{Materials and Methods}

\subsection{Study Areas}

For the purpose of this paper, two study areas were delimited. Unnatural spruce monocultures growing in the lowlands or lower mountains represents the area "Biely kríž" (Figure 1), which is situated near Rača in the Malé Karpaty Mountains (Western Slovakia) (Figure 2). The area representing natural mountain stands is situated near the Osobitá Mt. (Figure 1) in the Tatra Mountains, Slovakia (Figure 2). Further description of the study sites is included in (Table 1). 

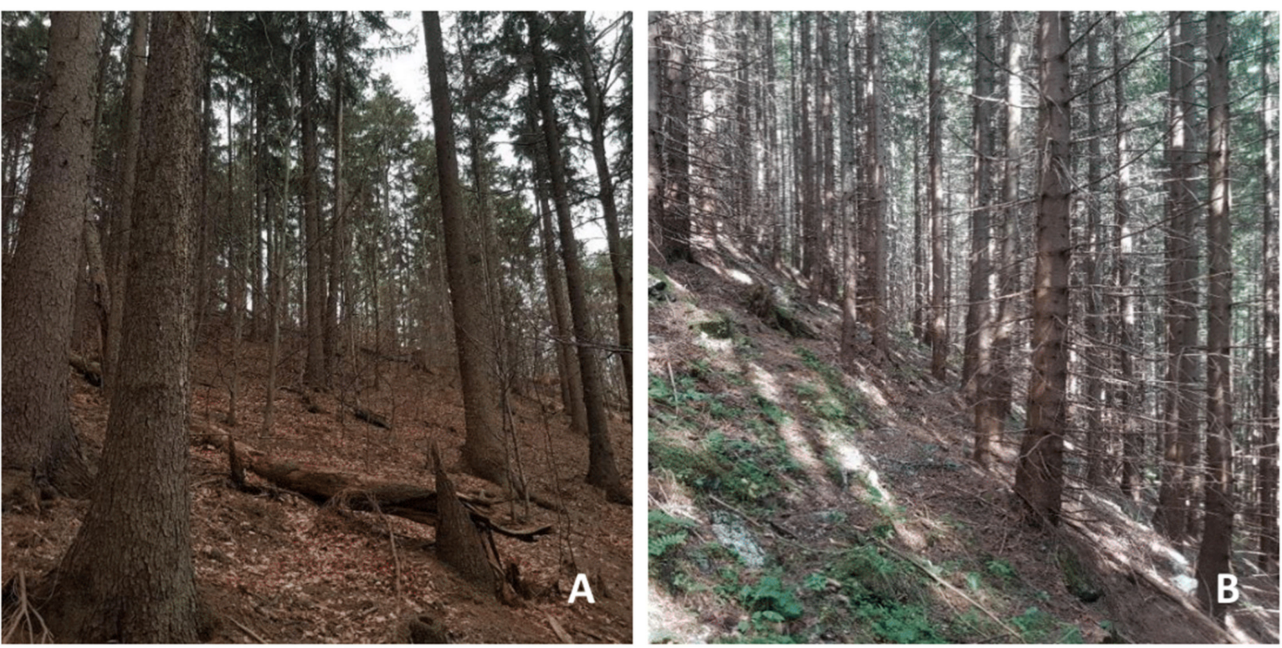

Figure 1. Spruce monoculture at Biely kríž (A) and succesive spruce stand at Osobitá (B).

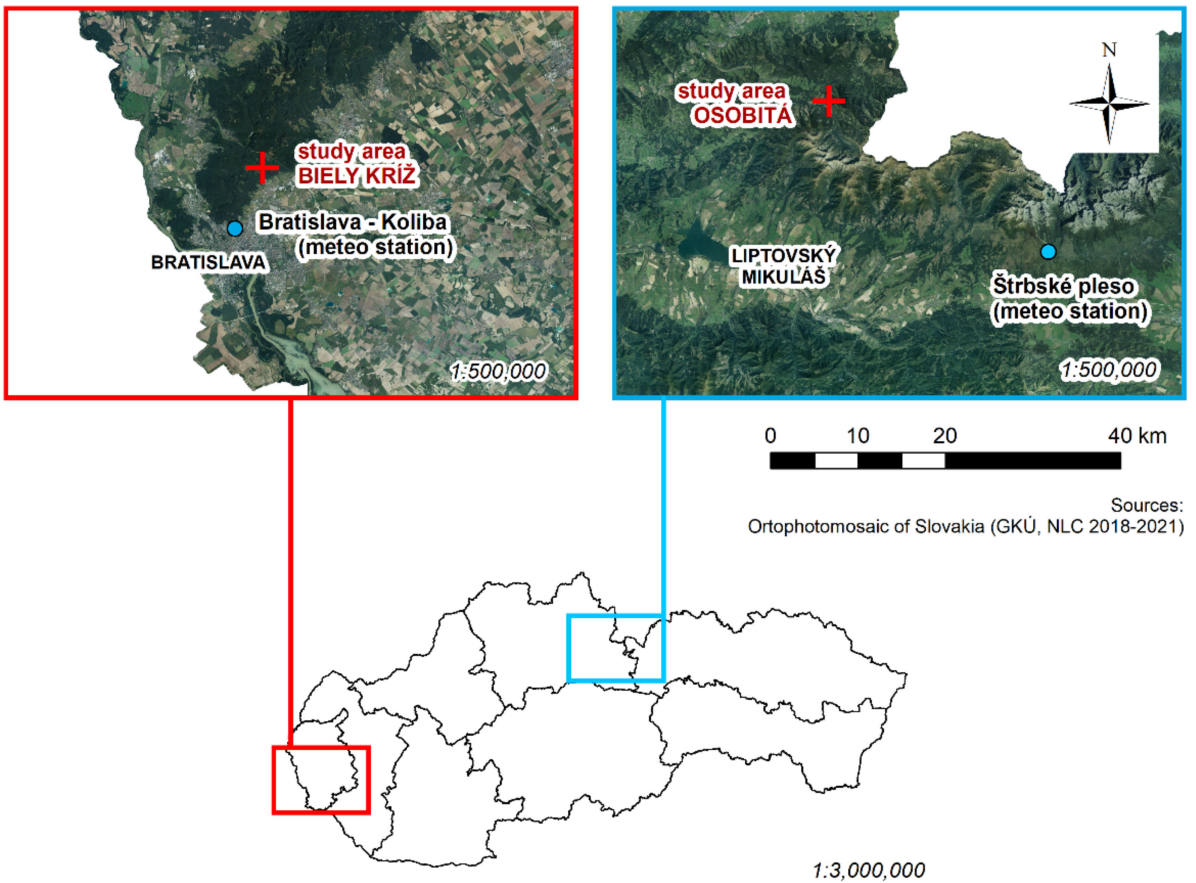

Figure 2. Location of the study areas.

Table 1. Description of the study areas.

\begin{tabular}{ccc}
\hline Study Area & Biely Kríž & Osobitá \\
\hline Number of plots & 1 & 1 \\
Plot size (ha) & 1 & 1 \\
Location & $\mathrm{N} 48.2329^{\circ} \mathrm{E} 17.1405^{\circ}$ & $\mathrm{N} 49.2589^{\circ} \mathrm{E} 19.7032^{\circ}$ \\
Year of measurement & 2019 & 2019 \\
Number of cores & 50 & 58 \\
Average altitude $(\mathrm{m})$ & 390 & 1120 \\
Average slope $\left(^{\circ}\right)$ & 35 & 15 \\
Aspect & SW & $\mathrm{S}$ \\
Soil type & Cambisoil & Rendzina \\
Forest plant community & & Piceion excelsae \\
Stand age & 120+ years & $80+$ years \\
Stand origin & Planted monoculture & Successive stand \\
\hline
\end{tabular}




\subsection{Field Sampling and Laboratory Samples Processing}

Field research was performed at Biely kríž in June 2019 and at Osobitá in July 2019. Increment cores of $P$. abies were collected by commonly used methodology as described by Cook and Kairiukstis [23]. Each tree core was extracted by a Pressler increment borer (Mora Coretax, $400 \times 0.5 \mathrm{~mm}$ ) at breast height, perpendicular to the vertical tree axis, as well as perpendicular to the slope direction in order to minimize the effect of reaction wood and the presence of tree ring eccentricity. It was subsequently deposited in a protective foil, and the GPS coordinates of the tree were marked. A total of 30 trees were sampled at each plot. Only trees without any visible damages or apparent worsened health were sampled. Furthermore, we aimed to maintain the highest possible dispersion of the analyzed trees among the area of interest.

Processing of the samples was based on the standard procedures described by Stokes and Smiley [24] or Speer [25]. All the collected cores were fixed in woody supports and sanded with sandpaper until the tree rings were clearly visible. Afterward, the tree ring widths were measured for each plot separately. A dendrochronological TimeTable device (with $0.01 \mathrm{~mm}$ accuracy) connected with a PC and PAST4 software [26] was used for this purpose. Individual tree rings were counted, and all tree ring series were crossdated amongst each other (for each plot separately) to detect all possible dating errors caused by the presence of false, missing, or wedging rings. When dating errors were detected, problematic tree rings were manually corrected. Moreover, cross-dating enabled the absolute synchronization of incomplete tree ring series (with the youngest tree rings absent due to their problematic field extraction). After initial visual and statistical tree ring series synchronization in PAST4, a second check of cross-dating accuracy was performed in COFECHA [27]. After including this procedure, each tree ring was assigned the correct year of its origin, thereby resulting in the chronologies becoming stronger.

The natural aging trend of radial tree growth was found to play a major role in the resulting raw values of TRW. In the initial phase of tree growth, TRWs have generally been proven to be wider, and with increasing age, become thinner. This is likely why the operation of detrending is a crucial part of editing tree ring chronologies. Using ARSTAN software [28], raw TRW values were transformed to detrended RWI (Ring Width Index) values, and their standard deviation values were computed. Due to a visually observed, linear-like decreasing trend of absolute TRW values that corresponded to the character of ecological competition in the studied forest stand [3], either a negative exponential curve or linear regression was used as the appropriate functions for detrending.

\subsection{Building Climate Data Chronologies}

Temperature and precipitation variables used in the subsequent dendroclimatic regression analysis are listed in (Table 2).

Table 2. Mezoclimatic variables used in dendroclimatic regression analysis.

\begin{tabular}{cc}
\hline Variable & Abbreviation \\
\hline Mean annual temperature & TY \\
Mean annual temperature of the previous year & TPY \\
Mean monthly temperature & TM1-TM10; TP10-TP12 * \\
Mean temperature of the growing season & TGS \\
Mean temperature out of the growing season & TXGS \\
Annual precipitation & PY \\
Monthly precipitation & PM1-PM10; PP10-PP12 * \\
Precipitation of the growing season & PGS \\
Precipitation out of the growing season & PXGS \\
\hline
\end{tabular}

* Mean values of the previous year's months.

For the years 1961-2009, all temperature and precipitation data were obtained from CARPATCLIM. This project provides a wide range of gridded climate data for the Carpathian region. Temperature and precipitation time series for the years 2010-2018 were provided 
by the Slovak Hydrometeorological Institute. In the case of Biely kríž, data from the Bratislava-Koliba station were used. For Osobitá, we used measurements from the Štrbské pleso station.

\subsection{Statistical Processing}

Based on the data availability and the need to capture the local impacts of the climate change on the radial tree growth, the time period 1961-2018 was selected for our analysis. In order to statistically express the relationship between the time series of climate variables and RWI chronology, we used the Spearman correlation coefficient (based on the order of the variables). The choice of this coefficient was based on the Shapiro-Wilk normality test, which showed that the obtained data were not from a normal distribution.

At first, we computed the Spearman coefficient separately for each area of interest for the entire period observed, as well as each climatic characteristic. We used the cor.test function in R Studio. Relationships were considered significant when $p<0.05$ (in this case, corresponding with $r_{s}>0.26$ and $r_{s}<-0.26$ with 58 observations of each variable). Secondly, we intended to capture the temporal variability of the Spearman coefficient during the observed time period. To receive the most detailed data possible, we used a 20-year running window separately for each area of interest, as well as for each variable. These coefficients were computed using the RolWinMulCor package and rolwincor_1win function in R Studio [29]. In the case of the running Spearman correlation coefficient with a window length of 20 years and 58 observations for each variable, the significant criterion $p<0.05$ corresponds to $\mathrm{r}_{\mathrm{s}}>0.45$ and $\mathrm{r}_{\mathrm{S}}<-0.45$.

\section{Results}

\subsection{RWI Chronologies}

A total of 50 increment cores were obtained at Biely kríž. The resulting detrended chronology reached the EPS value of 0.85 in 1949, and the Rbar value was 0.297 (Table A1). In the case of Osobitá, we collected 58 samples. The critical EPS value of 0.85 was reached in 1954, and the Rbar value was 0.299 (Table A2).

When comparing the detrended chronologies of both study areas (Figure 3), significantly higher sensitivity can be observed in the case of the planted, low-lying spruce monoculture at Biely kríž (especially between 1996 and 2002). Our findings also show generally higher standard deviations in this study area. However, a detrended chronology of the natural mountain stand at Osobitá expresses lower sensitivity with weaker fluctuation over the entire observed period.

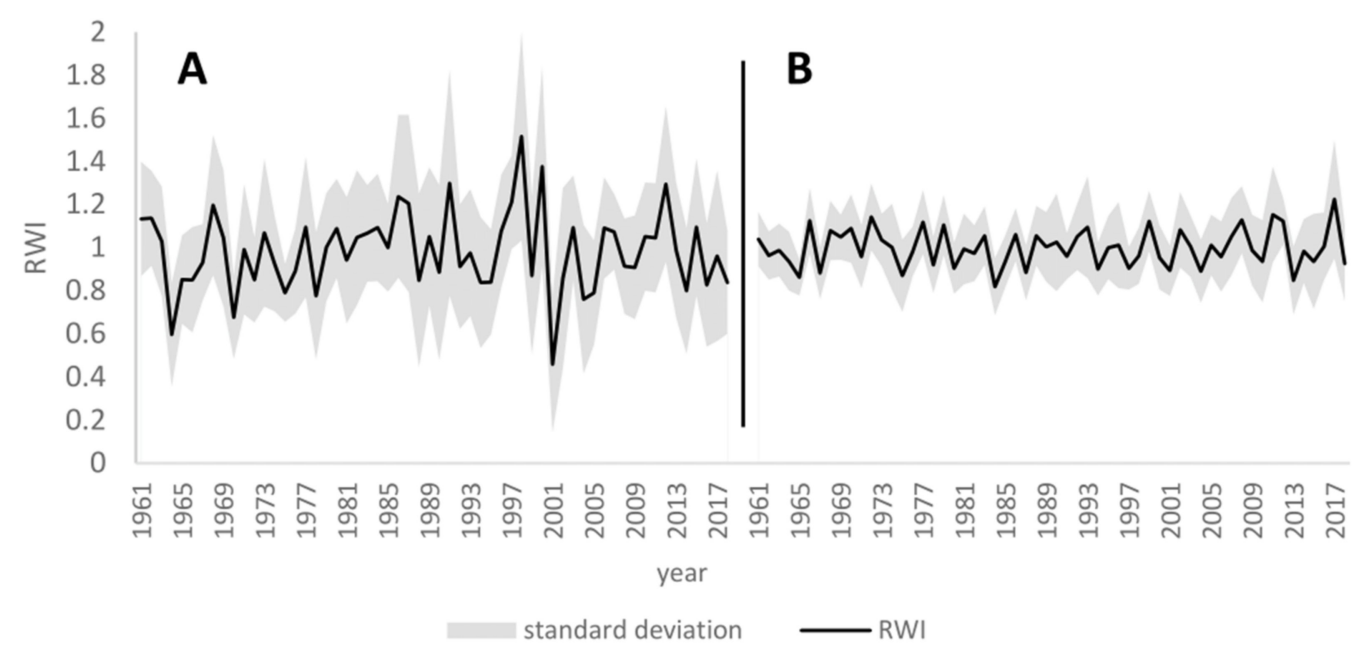

Figure 3. Comparison of the detrended chronologies of Biely kríž (A) and Osobitá (B). 


\subsection{Temperature and Precipitation Temporal Variability}

Mean annual temperature (1961-2018) reached $9.8^{\circ} \mathrm{C}$ at Biely kríž and $5.1^{\circ} \mathrm{C}$ at Osobitá. When analyzing the temporal trends of mean annual temperatures (Figure 4), a similar interannual fluctuation and a gradual rise can be observed. When compared to the mean temperature between the 1960s and 1980s, the mean annual temperature was higher in the twenty-first century by $1.51^{\circ} \mathrm{C}$ at Biely kríž and by $1.31{ }^{\circ} \mathrm{C}$ at Osobitá. Moreover, the seven warmest years of the entire observed period occurred during the twenty-first century at Osobitá, and nine of them at Biely kríž. Four of these years $(2007,2014$, 2015, and 2018) were mutual for both study areas.

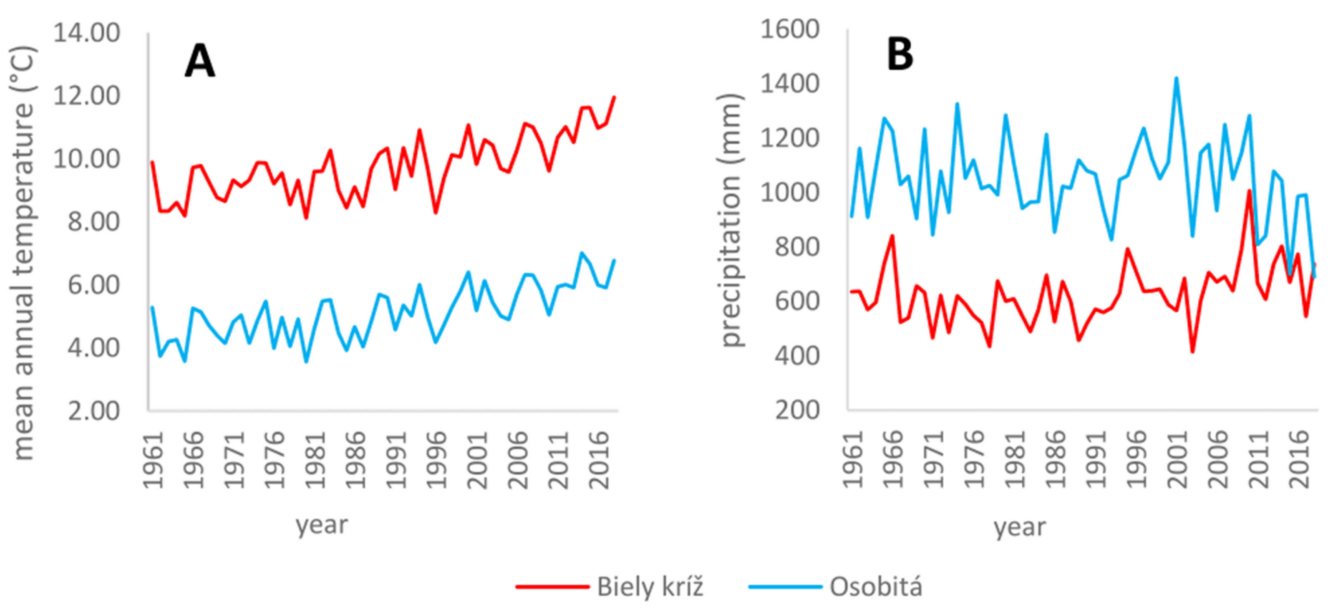

Figure 4. Timelines of mean annual temperature (A) and precipitation (B) (1961-2019).

Average annual precipitation reached $625 \mathrm{~mm}$ at Biely kríz and $1050 \mathrm{~mm}$ at Osobitá. In the twenty-first century, we detected both a moderate increase of precipitation at Biely kríž and a moderate decrease at Osobitá (Figure 4). Moreover, the differences in annual precipitation between the study areas were lowest in the twenty-first century. When compared to the mean annual temperatures, the driest years were not clustered in one time period.

\subsection{Relationships between Tree Ring Record and Climatic Variables}

At Biely kríž, no significant relationships between RWI and temperature variables were found. Negative correlations prevailed outside the growing season and in TM7. In contrast, temperatures seem to play a greater role at Osobitá. During the growing season, its impact is clearly positive, except for TM7 and TM9. Moreover, correlations were proven to be statistically significant in the case of TM3 $\left(r_{\mathrm{s}}=0.29\right)$, TM5 $\left(r_{\mathrm{s}}=0.27\right)$, and TM6 $\left(r_{s}=0.31\right)$. For the rest of the months, negative relationships are more common, with one significant correlation in the case of TP11 $\left(r_{s}=-0.27\right)$ (Figure 5).

When analyzing the relationships between RWI and precipitation variables, insignificant negative correlations are typical for the growing season at Biely kríž. During the late autumn and winter months, the character of the relationships is rather inconsistent. Despite this, we found a significant positive correlation in PM1 $\left(r_{\mathrm{s}}=0.32\right)$. At Osobitá, negative relationships prevailed, except for PPY, PP11, PP12, PM7, PM8, and PM10. No significant correlation was found (Figure 6). 


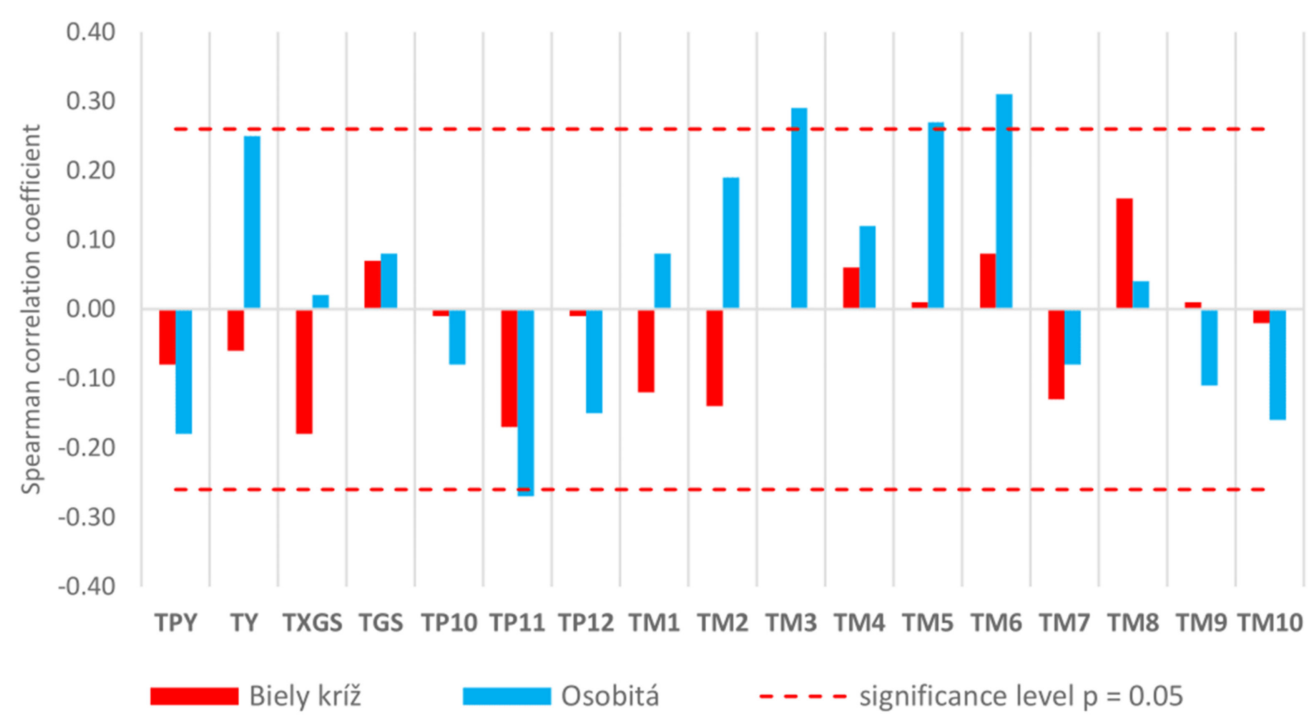

Figure 5. Dependance of RWI chronology on temperature variables (1961-2018).

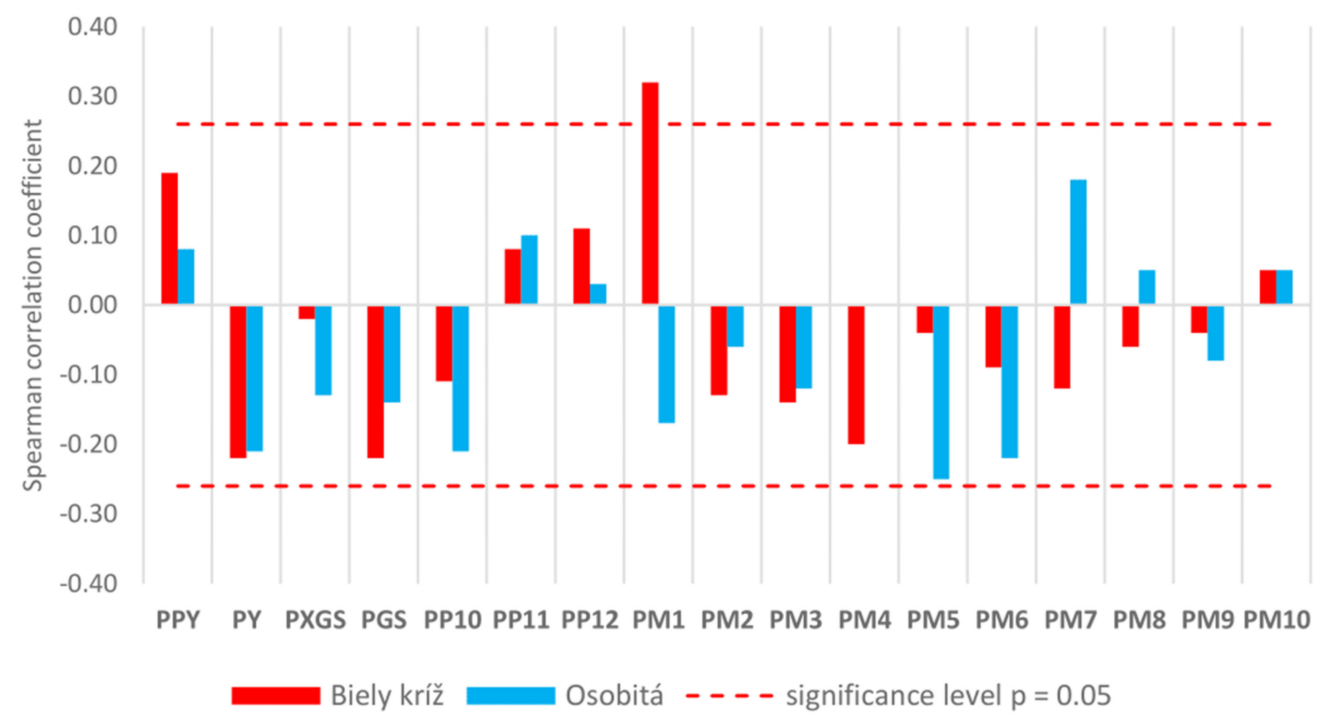

Figure 6. Dependance of RWI chronology on precipitation variables (1961-2018).

\subsubsection{Temporal Variability of the Temperature-Growth Relationships}

At Biely kríž (Figures 7 and A1), negative relationships with the TY and TXGS were strengthened moderately up to intervals with the ordinal numbers (below marked as " $\mathrm{I}^{\text {") }}$ ) 18-20. During these intervals, statistically significant relationships were found. Afterward, correlations were weakened and transformed fluently into moderately strengthened positive ones (significant for TGS during I 37-39). For the most part, TXGS correlated both weakly and negatively.

Correlations with TY and TGS were relatively consistent, weak (TGS slightly weaker), as well as positive during the observed time period at Osobitá (Figures 7 and A2). However, correlations with TXGS were rather incoherent. A moderate strengthening of the positive relationships took place up to I 11-12 (significant correlations). Afterward, we detected a descent in the strength and fluent transformation to the consistent negative correlations from I 30. 

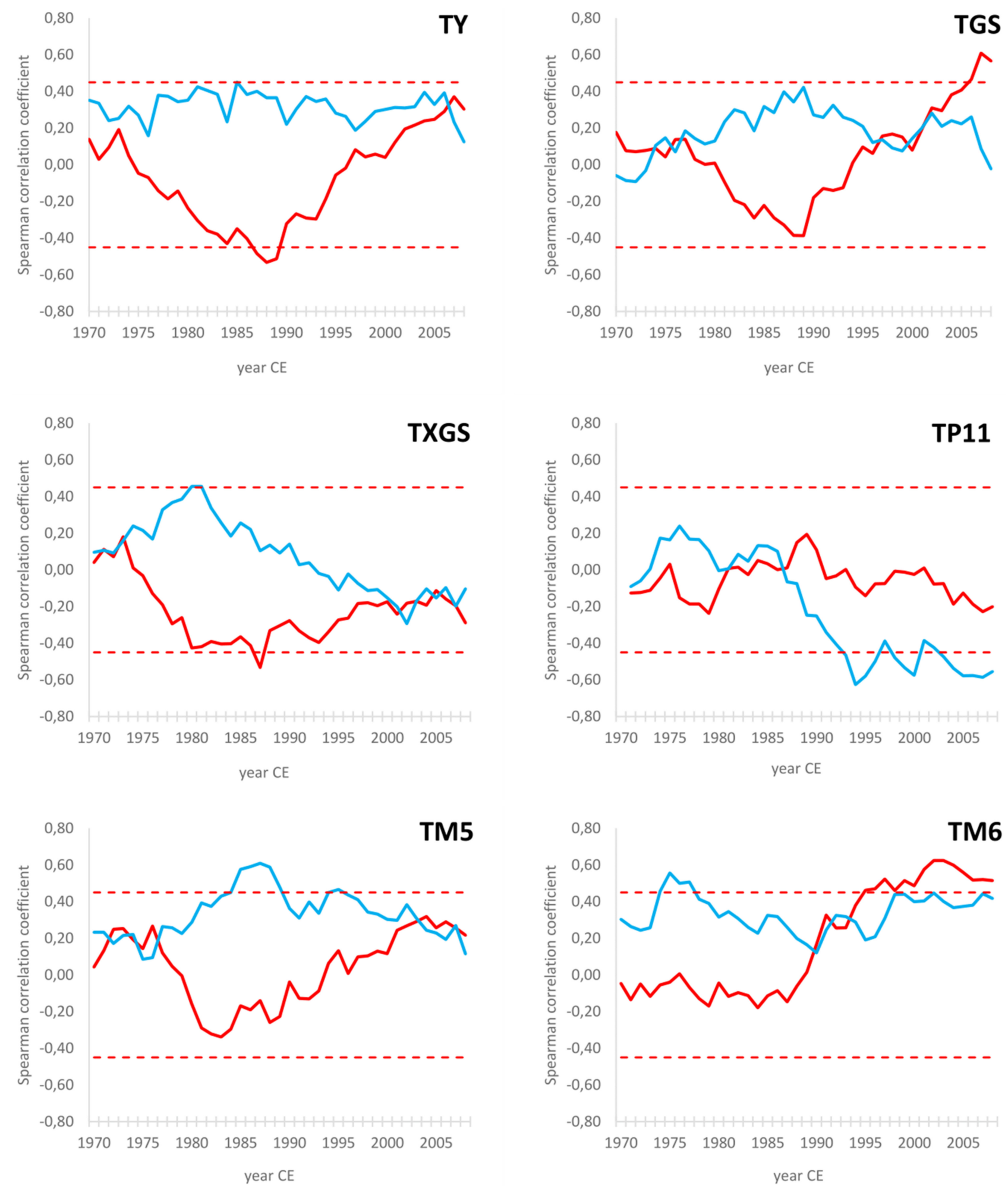

Figure 7. Running Spearman correlations between RWI chronology and timelines of selected temperature variables. = Biely kríž, = Osobitá, $----=$ significance level $p=0.05$, year $\mathrm{CE}=$ central year of correlation window.

When comparing Biely kríž and Osobitá (Figures 7 and A1 and A2), low-lying forest reacted more inconsistently on TY and TGS than mountain forest, while in the case of TXGS, a reverse trend was detected. Moreover, after I 37, we found a significant decrease in the strength of relationships with TY and TGS at Osobitá, as well as an increase of this strength at Biely kríž. In both cases, TPY correlated insignificantly. 
Negative, weak, and rather consistent correlations with RWI are typical for the months outside the growing season at Biely kríž (Figures 7 and A1). As for the growing season itself, a long sequence of significant, positive correlations took place with the TM6 (I 26-39). There is a visible trend (also captured by the above-mentioned TGS) of strengthening of the positive relationships with TM4-TM6 and TM8 from I 21 to 26.

At Osobitá (Figures 7 and A2), climate-growth relationships with the TMs are quite inconsistent. A continuous sequence of statistically significant negative correlations was detected for TP11 in I 24-I 39. As for the trends, only TM3-TM6 were predominantly positive, while in the case of TP11-TP12 and TM7-TM10, negative relationships prevailed. Very weak relationships are characteristic for TM7 and TM8.

The months outside the growing season correlated consistently at Biely kríž. At Osobitá, fluctuating monthly trends with a slightly higher number of statistically significant relationships had taken place (Figures 7 and A1 and Figure A2). During the growing season, a clearly positive influence of the TM4-TM6 was detected at Osobitá. In contrast, a similar positive influence of these TMs at Biely kríž could be found only in the final part of the observed period. For both study areas, TM7 and TM8 correlated inconsistently and quite weakly (few significant relationships were recognized in the case of Biely kríž).

\subsubsection{Temporal Variability of the Precipitation-Growth Relationships}

At Biely kríž (Figures 8 and A3), PY and PGS correlated predominantly weakly and negatively. However, PPY showed a strengthening of the positive relationships from I 17 , culminating in an uninterrupted series of statistically significant correlations during I 28-39. Insignificant correlations with PXGS turned from positive to negative in I 17.

As for Osobitá (Figures 8 and A4), negative correlations with PY and PGS dominated. Significant relationships with PGS were found in I 13-22, while only locally with PY. Moreover, at the end of the observed period, correlations with PGS weakened. In the case of PPY, relationships turned positive and became stronger after I 11. The most inconsistent were responses to PXGS. Positive correlations strengthened up to I 13-14 (significant values). Afterward, they gradually transformed into strong and negative ones (statistically significant in I 38-39).

In conclusion, PY and PGS correlated negatively in both study areas, although the relationships were stronger at Osobitá. The trend of turning the positive influence of PXGS into a negative one was characteristic for both stands as well (at Biely kríž, the breaking point occurred later. However, the change was more explicit at Osobitá). Finally, both forests showed positive relationships with PPY. At Biely kríž, these correlations occurred later and were also much stronger (Figures 8 and $\mathrm{A} 3$ and Figure A4).

When considering the influence of monthly precipitation on radial tree growth outside the growing season at Biely kríž (Figures 8 and A3), the months can be split into those with either a prevailing positive (PP11-PM1) or negative bound (PP10, PM3). However, the relationships were predominantly weak. Significant values were only observed locally. Correlations with PM2 turned from positive to negative in I 18 and were statistically significant in I 28-31 and I 35-37. During the growing season, relationships with the PMs were very weak and inconsistent. PM5 showed mainly positive influence, while PM4 and PM9 a negative one (nevertheless, at the beginning of the observed period, the character was the complete opposite in the case of PM5 and PM9). All the other months correlated inconsistently.

At Osobitá (Figures 8 and A4), PMs correlated variably and weakly outside the growing season, with a few random significant relationships detected. Additionally, a changing trend of negative-positive-negative can be observed, with a "positive window" length of approximately 20 intervals. In the case of PP11, positive relationships either remained or became significant during I 21-I 32. During the growing season, the relationships were even more fluctuant and weak. Only a few significant bounds were detected. PM5 was the only variable that correlated consistently during the entire observed period. 
In conclusion, we can state that the dendroclimatic relationships with the monthly precipitation were weak and relatively inconsistent in both study areas.
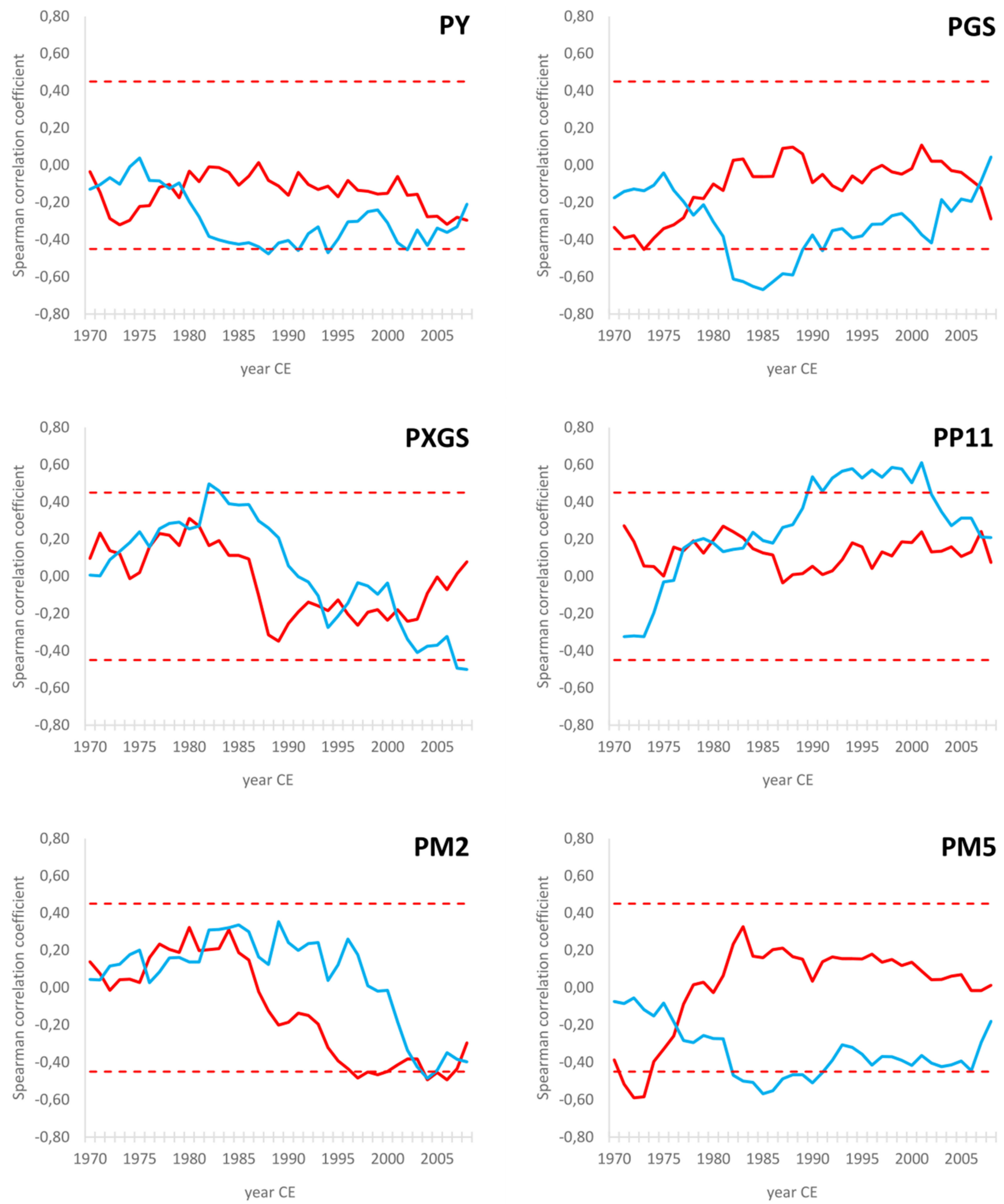

Figure 8. Running Spearman correlations between RWI chronology and timelines of selected precipitation variables. = Biely kríž, = Osobitá, - - - - = significance level $p=0.05$, year CE = central year of correlation window. 


\section{Discussion}

\subsection{Temperature as a Driver of the Radial Picea Abies Growth}

When considering the entire period observed, not one single significant correlation to the temperature variables was found at Biely kríz. Using a running correlation, a more detailed analysis implies a possible explanation-the seasonal variables TGS and TY correlated inconsistently. The predominant character of the relationship changed when strong, negative bounds turned into strong, positive ones (starting in the 1980s). The possibility of inspection of such changes is a crucial advantage of the method of running correlations, especially under conditions of dynamic environmental changes that are connected to anthropogenetic pressure and the related climate change.

However, trees growing at Osobitá reacted to the growing season's mezoclimate fluctuations relatively consistently and positively; however, the individual relationships were predominantly weak. These findings are supported by Vitali et al. [7], who claim that the stands of the higher elevations are less affected by summer climate variation when compared to the low-lying stands (although the pronounced negative relationships of the lower stands were not confirmed for Biely kríž). Similar results were proposed by Sedmáková et al. [10] and Hartl-Meier et al. [30]. We suggest that the aforementioned incoherency of the climate-growth relationships at Biely križ is due to its location outside the natural species distribution area. Such deviation from an optimum range causes worsened health conditions, as well as an inability to effectively react to climate-driven stress on the basis of Shelford's law of tolerance [31].

When considering the period outside the growing season, Biely kríž showed relatively consistent, weak, and negative responses. Nevertheless, Osobitá correlated incoherently and weakly, turning from predominantly positive relationships to negative ones. Furthermore, a significant negative correlation of the entire observed period was found in the case of the TP11 (detailed inspection showed a long sequence of strong negative relationships since 1984). Significant correlations are not exceptional in the autumn and winter months, as was previously confirmed by the findings of several authors $[5,7,10]$; however, their occurrence is not consistent in the individual study areas.

It is clear that the monthly temperatures of the late spring and early summer (May and June) had the greatest and most sustainable impact on the resulting radial growth In this period, a major part of annual radial growth took place [32]. However, TM7 and TM8 correlated very weakly and fluctuated. We assume that the irregular heat waves, which are typical for late summer, are the main reason for this phenomenon. They cannot be reliably captured by the mean values of monthly temperatures. Such inconsistency in the temperature-growth relationships of individual months of the growing season was reflected in a weak correlation with the TGS.

Our results suggest that the temperature signal varies in the low-lying mountain forest and in the mountain spruce forest. When considering the entire observed period, Osobitá showed several significant correlations with monthly values, while Biely kríž correlated exclusively weakly. The temporal variability of the temperature-growth relationships was significantly higher on Biely kríž, however, only in the case of the growing season variables. Based on these findings, we partially confirm our second hypothesis.

\subsection{Precipitation as a Driver of the Radial Picea Abies Growth}

When considering the entire observed period, only one significant correlation with the monthly precipitation was found in each study area. Even at a closer look, precipitationgrowth relationships at Biely kríž appeared to be very weak and predominantly negative; however, there has been an interesting trend of strengthening of positive correlations with the PPY since the latter half of the 1970s.

Osobitá showed stronger and relatively sustainable negative relationships with the seasonal precipitation variables (even though there has been visible weakening since the 1990s). The only exception is PXGS, which turns from positive to negative during the 1980s. One possible explanation might be a reduced snowfall or its faster melting. As a result, this 
causes a lack of moisture in the spring and summer months. The form of precipitation was not recorded in the analyzed climatic data.

It is generally agreed that spruce is a species that is extremely non-resilient to droughts $[1,33]$. This variable is also related to climate change. A series of droughts, as well as extreme precipitation during storms, cannot be reliably captured by the monthly variables used. This is why new or briefly used variables will be necessary for dendroclimatological analyses in the future (e.g., average summer drought duration, its frequency, precipitation of storms, etc.). As noted by Sedmáková et al. [10], a slight change of precipitation does not outweigh higher evapotranspiration. Although there was not any notable change of precipitation in our study areas during the period observed, we can assume its aforementioned "hidden" effect.

In summary, negative relationships with precipitation variables prevailed in both study areas; however, the correlations were mostly weak. The study areas differed particularly in the cases of PM1, PM5, and PM7, as well as in a variety of local strengthening of relationships. In the case of Osobitá, running correlations proved to have slightly stronger relationships.

Considering temporal variability of the precipitation-growth relationships, these were more consistent (though weaker) on Biely kríz. However, this difference was less significant than in the case of temperature variables. While the second hypothesis was partially valid in the case of temperatures, we reject it with regard to these findings.

\subsection{Identification of Temperature-Driven Signal and Moisture-Driven Signal}

Hartl-Meier et al. [30] claim that climate signal limits spruce growth by increased temperatures and lowered precipitation in the lower mountains, as well as by decreased temperatures and higher precipitation under the tree line. Sedmáková et al. [10] consider this effect to be even more prominent in the conditions of Slovakia. In the second forest vegetation zone (altitude of Biely kríž), there is moisture-driven tree growth, while in the fifth and sixth forest vegetation zone (altitude of Osobitá), temperature-driven growth occurs.

Temperature-driven signal is characterized by either weak correlations or strong negative correlations with the precipitation variables, as well as strong positive relationships between RWI chronology and timelines of temperature variables. In contrast, strong positive correlations with precipitation are typical for moisture-driven signals, as well as with weak or strong negative correlations with temperatures.

The aforementioned signs of temperature-driven signals correspond to our findings at Osobitá, especially when considering the annual variables of the growing season. In contrast, the influence of mezoclimatic variables outside the growing season is rather ambiguous. The identified growth relationships at Biely kríz differ from the presented moisture-driven model. Relationships with both temperature- and precipitation-related variables are weak and fluctuant.

These findings imply that climate-growth relationships differ in the natural mountain stand (represented by Osobitá) and the low-lying monoculture (represented by Biely kríž). However, it must be noted that that the study areas are situated in contrasting climate regions. Taking this fact into consideration is crucial when interpreting the results. While the findings at Osobitá display the signs of temperature-driven growth, the same cannot be claimed about Biely kríž. Dendroclimatic relationships of this study area were generally less consistent, which can be due to the trees' higher age, unnatural growth conditions, and lower resilience related to the various forms of stress. With regard to these findings, our first hypothesis was only partially verified.

\subsection{Limitations and Further Research Suggestions}

Although we intended to maintain homogenous morphometric parameters in both study areas, there are several deviations of the mean slope and aspect that may cause additional noise. Additionally, the resulting temperature and precipitation timelines have 
been merged from the two different sources (The Slovak Hydrometeorological Institute and CARPATCLIM), which is not an ideal option but reflects the current climatic data availability.

For the years 2010-2018, data collected from the Štrbské pleso station were used for dendroclimatic regression analysis at Osobitá. This station lies approximately $20 \mathrm{~km}$ east of the study area; however, it shares the same altitude and aspect. In the case of temperatures, only the position of the analyzed stands in the closed valley could cause certain deviations. As for precipitation, the differences could be more significant. Osobitá lies on the windy western edge of the Tatras with Štrbské Pleso in its center. Weakened relationships at the end of the observed period might be a consequence of these different climatic conditions.

Several authors have previously analyzed the mutual relationship between the temperature and precipitation signal, as well as its "mixed" influence on spruce radial growth $[7-9,11,32,34]$. The connection of this phenomenon to tree growth, as well as an assessment using a new "mixed" variable, is the subject of further research.

Apart from temperature and precipitation, there are also other drivers that influence spruce growth. In addition to the geographical aspects of the stand location, different forms of anthropogenetic pollution $[6,8,9,32]$ or increase of ozone concentrations $[35,36]$ have a crucial impact as well. These are also a common subject of dendroclimatological regression analysis. Some of them can even influence a climate-driven signal. In the Czech Republic, acid pollution was found to be one of the most important drivers of varying divergence of tree growth from the summer temperatures in the 1980s [6,9]. For a complex assessment of the climate-growth relationships of the Slovak spruce stands, even these anthropogenetic variables must be taken into account in future studies.

\section{Conclusions}

In our research, the dendroclimatological relationships between RWI chronologies and selected mezoclimatic variables in the context of ongoing climate change from 1961 to 2018 were analyzed. We provided a comparison between the planted, low-lying Picea abies stand (Biely kríž) and the natural mountain one (Osobitá). We can therefore assume a different response to the recent climate fluctuations and connected climate-driven stress in each study area.

As the research has clearly demonstrated, climate-growth relationships vary under the aforementioned conditions. While the monoculture displayed rather inconsistent reactions to the growing season's mean temperatures during the observed period, this was typically positive for the natural spruce forest, although with weak dependence. In contrast, mean temperatures outside the growing season correlated at Biely križ coherently, while they fluctuated at Osobitá. In both cases, the strongest relationships were detected in the early summer mean temperatures. As for precipitation, both study areas correlated inconsistently outside the growing season, yet consistently during the growing season (Osobitá showed stronger negative dependence, while Biely kríž showed almost no dependence at all).

At Osobitá, the relationships observed meet typical signs of temperature-driven tree growth, which have been previously described by several authors. Moreover, we can confirm the statement that the stands located in the natural Picea abies geographical distribution were less affected by a gradual mean temperature rise related to climate change when compared to the low-lying monocultures. More specifically, in the case of Biely kríž, non-uniformity of the growth relationships can be attributed to old age, poor health condition, and worsened resilience to the recent climate fluctuations.

These findings are applicable mainly in forestry. They can contribute to a deeper understanding of the local impacts of climate change on the Picea abies stands growth, as well as be considered in forest management decision-making related to the relationship between tree species and their most suitable growth conditions. 
Author Contributions: Conceptualization, V.Š. and I.R.; methodology, V.Š., I.R., K.Š. and P.B.; formal analysis, V.Š., K.Š. and P.B.; investigation, V.Š., I.R. and K.Š.; resources, V.Š., I.R. and K.Š.; data curation, V.Š.; writing - original draft preparation, V.Š.; writing—review and editing, V.Š., I.R., K.Š. and P.B.; visualization, V.Š. All authors have read and agreed to the published version of the manuscript.

Funding: This research was funded by the Scientific Grant Agency of the Ministry of Education of the Slovak Republic and the Slovak Academy of Sciences, the grant VEGA 1/0247/19 "Assessment of land-use dynamics and land cover changes".

Data Availability Statement: CARPATCLIM data are freely available at http:/ /www.carpatclim-eu. org/pages/download/default.aspx (accessed on 13 January 2021). Data from the Slovak Hydrometeorological Institute cannot be published.

Conflicts of Interest: The authors declare no conflict of interest.

\section{Appendix A}

Table A1. RWI timeline of Biely kríž.

\begin{tabular}{cccccccc}
\hline Year & RWI & Year & RWI & Year & RWI & Year & RWI \\
\hline 1961 & 1.13 & 1976 & 0.89 & 1991 & 1.30 & 2006 & 1.09 \\
1962 & 1.14 & 1977 & 1.10 & 1992 & 0.91 & 2007 & 1.07 \\
1963 & 1.03 & 1978 & 0.78 & 1993 & 0.98 & 2008 & 0.91 \\
1964 & 0.60 & 1979 & 1.00 & 1994 & 0.84 & 2009 & 0.91 \\
1965 & 0.85 & 1980 & 1.09 & 1995 & 0.84 & 2010 & 1.05 \\
1966 & 0.85 & 1981 & 0.94 & 1996 & 1.08 & 2011 & 1.05 \\
1967 & 0.93 & 1982 & 1.05 & 1997 & 1.21 & 2012 & 1.30 \\
1968 & 1.20 & 1983 & 1.07 & 1998 & 1.52 & 2013 & 0.99 \\
1969 & 1.04 & 1984 & 1.09 & 1999 & 0.87 & 2014 & 0.80 \\
1970 & 0.68 & 1985 & 1.00 & 2000 & 1.38 & 2015 & 1.09 \\
1971 & 0.99 & 1986 & 1.24 & 2001 & 0.46 & 2016 & 0.83 \\
1972 & 0.85 & 1987 & 1.20 & 2002 & 0.86 & 2017 & 0.96 \\
1973 & 1.07 & 1988 & 0.85 & 2003 & 1.09 & 2018 & 0.84 \\
1974 & 0.92 & 1989 & 1.05 & 2004 & 0.76 & & \\
1975 & 0.79 & 1990 & 0.89 & 2005 & 0.79 & & \\
\hline
\end{tabular}

Table A2. RWI timeline of Osobitá.

\begin{tabular}{cccccccc}
\hline Year & RWI & Year & RWI & Year & RWI & Year & RWI \\
\hline 1961 & 1.04 & 1976 & 0.98 & 1991 & 0.96 & 2006 & 0.96 \\
1962 & 0.96 & 1977 & 1.12 & 1992 & 1.05 & 2007 & 1.05 \\
1963 & 0.99 & 1978 & 0.92 & 1993 & 1.09 & 2008 & 1.13 \\
1964 & 0.94 & 1979 & 1.10 & 1994 & 0.90 & 2009 & 0.99 \\
1965 & 0.86 & 1980 & 0.90 & 1995 & 1.00 & 2010 & 0.94 \\
1966 & 1.12 & 1981 & 0.99 & 1996 & 1.01 & 2011 & 1.15 \\
1967 & 0.88 & 1982 & 0.97 & 1997 & 0.90 & 2012 & 1.12 \\
1968 & 1.08 & 1983 & 1.06 & 1998 & 0.96 & 2013 & 0.85 \\
1969 & 1.05 & 1984 & 0.82 & 1999 & 1.12 & 2014 & 0.98 \\
1970 & 1.09 & 1985 & 0.94 & 2000 & 0.95 & 2015 & 0.94 \\
1971 & 0.96 & 1986 & 1.06 & 2001 & 0.89 & 2016 & 1.01 \\
1972 & 1.14 & 1987 & 0.88 & 2002 & 1.08 & 2017 & 1.22 \\
1973 & 1.04 & 1988 & 1.05 & 2003 & 1.01 & 2018 & 0.93 \\
1974 & 1.00 & 1989 & 1.00 & 2004 & 0.89 & & \\
1975 & 0.87 & 1990 & 1.02 & 2005 & 1.01 & & \\
\hline
\end{tabular}




\begin{tabular}{|c|c|c|c|c|c|c|c|c|c|c|c|c|c|c|c|c|c|c|}
\hline & & & & & & & & & & & & TM4 & TM5 & M6 & TM7 & M8 & M9 & \\
\hline 1 & 961 - & & & & & & & & & & & & & & & & & \\
\hline 2 & 962 & 23 & ? & ( & 08 & & & & & & & 03 & 13 & .14 & 0.14 & 21 & .05 & 22 \\
\hline 3 & 06 & & & & & & & & & & & & .25 & 0.05 & -0.06 & .10 & 07 & 19 \\
\hline 4 & & & & & & & & & & & & & & & & & & 17 \\
\hline 5 & $0<=$ & & & & & & & ( 01 & -0.18 & & & -0.09 & 0.19 & -0.05 & -0.03 & 0.11 & בחת & 201 \\
\hline 6 & & & & & & & & & & & & & & & & & & 0.1 \\
\hline 7 & & & & & & & & & & & & & & & & .09 & & 20 \\
\hline 8 & & & & & & & & & & & & & & .07 & & & & \\
\hline 9 & & & & & & & & & -0.30 & 0.18 & .17 & .03 & .05 & 0.13 & -0.18 & .00 & 11 & 40 \\
\hline 10 & & & & & & & & & & & & & & & & .00 & & \\
\hline 11 & & & & & & & & & -0.35 & .28 & .27 & .02 & .16 & 0.04 & 0.19 & . 01 & & 31 \\
\hline 12 & & & & & & & & & -0.32 & & & & -0.29 & & & & & \\
\hline 13 & & & & & & & & & & .35 & & & .32 & 0.10 & & 11 & & \\
\hline 14 & & & & & & & & & -0.46 & & & & & & & & & \\
\hline 15 & 94 & & & & & & & & .48 & & & & & 18 & & .20 & & \\
\hline 16 & & & & & & & & & -0.35 & & & & & & & & & \\
\hline 17 & & & & & & & & & -0.33 & & & & & .09 & & & & \\
\hline 10 & & & & & & & & & & & & & & & & & & \\
\hline 19 & & & & & & & & & & & & & & & & & & \\
\hline 20 & & & & & & & & & & & & & & & & & & \\
\hline 2. & & & & & & & & & & & & & & & & & & \\
\hline 22 & 001 & 28 & & & & & & & -0.19 & & & & & 0.33 & 0.45 & م10 & $0 ?$ & 0 \\
\hline 23 & & & & & & & & & & & & & & .26 & & 0.11 & 09 & \\
\hline 24 & & & & & & & & & & & & & & 0.26 & & & & 0 \\
\hline 25 & & & & & & & & & & & & & & .38 & & .01 & & \\
\hline 26 & & & & & & & & & & & & & & & & & & \\
\hline 27 & & & & & & & & & & & & & & & & 02 & & \\
\hline 28 & & & & & & & & & -0.17 & & & & & .52 & -0.24 & .10 & 01 & ? \\
\hline 29 & & & & & & & & & & & & & & & & & & \\
\hline 30 & & & & & & & & & -0.10 & -0.0 & & & & .51 & -0.19 & .13 & & ? \\
\hline 31 & & & & & & & & & & & & & & & & & & \\
\hline 32 & & & & & & & & & & & & & & & & 15 & & ? \\
\hline 33 & & & & & & & & & & & & & & & & & & \\
\hline 34 & & & & & & & & & & & & & & & & & & \\
\hline 35 & & & & & & & & & & & & & & 0.60 & & 0.40 & & ? \\
\hline 36 & & & & & & & & & & & & & & & & & & \\
\hline 37 & & & & & & & & & & & & & 0.29 & 0.52 & 0.02 & 0.50 & -0.05 & \\
\hline 38 & & & & & & & & & & & & & & & & 0.46 & & \\
\hline 39 & 0010 & 0 & & & & & -0.20 & & & & & 0.13 & 0.2 & & 0.27 & 0.38 & -0.01 & \\
\hline
\end{tabular}

\begin{tabular}{|c|c|c|c|c|c|c|c|c|c|}
\hline-0.8 & -0.6 & -0.4 & -0.2 & 0 & 0.2 & 0.4 & 0.6 & 0.8 & significant $(\mathrm{p}<0.05)$ \\
\hline
\end{tabular}

Figure A1. Running Spearman correlations between RWI chronology and timelines of temperature variables at B. kríž. 


\begin{tabular}{|c|c|c|c|c|c|c|c|c|c|c|c|c|c|c|c|c|c|c|}
\hline & & & Y & & GS & P10 & TP11 & TP12 & TM1 & TM2 & TM3 & TM4 & TM5 & TM6 & TM7 & TM8 & TM9 & TM10 \\
\hline 1 & $961-1980$ & & 0.35 & 0.10 & 0.06 & & & & .20 & .50 & 28 & 14 & 23 & .30 & .06 & .02 & 0.31 & 0.11 \\
\hline 2 & $1962-1981$ & .28 & 0.34 & 0.11 & -0.09 & 0.11 & -0.09 & -0.19 & -0.20 & 0.47 & 0.27 & 0.08 & 0.23 & 0.26 & -0.07 & 0.07 & -0.33 & -0.14 \\
\hline 3 & $1062 \quad 1082$ & -0.27 & & 0.09 & -0.09 & 0.12 & -0.06 & -0.19 & -0.18 & 0.48 & 0.23 & 0.13 & 17 & 0.24 & -0.09 & 0.07 & -0.37 & -0.15 \\
\hline 4 & $1964-1983$ & .20 & 25 & 0.16 & -0.03 & 0.16 & 0.00 & -0.15 & -0.16 & 0.41 & .25 & 0.19 & 022 & 0.26 & -0.02 & 0.07 & -0.36 & -0.14 \\
\hline 5 & $1965-1984$ & .26 & & 0.24 & 0.11 & 0.16 & 0.17 & -0.20 & -0.22 & 0.42 & .29 & 0.24 & 0.22 & 0.46 & 0.16 & 0.08 & -0.35 & -0.19 \\
\hline 6 & $1966-$ & .26 & 27 & 0.22 & 0.15 & 0.08 & 0.16 & -0.16 & -0.10 & .37 & 24 & .25 & .09 & .56 & 0.17 & 0.05 & .24 & 0.24 \\
\hline 7 & $1967-1986$ & -0.22 & 016 & 0.17 & 0.07 & 0.18 & 0.24 & -0.16 & -0.02 & 0.19 & 0.26 & 019 & 0.09 & 0.50 & 0.07 & -0.10 & -0.28 & -0.39 \\
\hline 8 & $1968-1987$ & 0.09 & & & & & & -0.15 & 0.04 & & & & 0.26 & 0.51 & 0.09 & 0.09 & -0.28 & -0.35 \\
\hline 9 & $1969-1988$ & -0.21 & & 0.37 & 0.14 & 0.26 & 0.17 & -0.06 & 0.15 & 0.13 & 0.34 & 012 & 0.26 & 0.41 & 0.14 & 0.10 & -0.31 & -0.29 \\
\hline 10 & $1970-1989$ & -0.25 & & & & 0.26 & 0.10 & -0.01 & 0.16 & 0.16 & & & 0.23 & 0.39 & 0.09 & 0.11 & -0.30 & -0.31 \\
\hline 11 & $1971-1990$ & -0.23 & 035 & 046 & 0.13 & 0.23 & 0.00 & 0.14 & 0.22 & 0.26 & 0.42 & 0.12 & 0.29 & 0.32 & 0.06 & 0.06 & -0.26 & -0.24 \\
\hline 12 & $1972-1991$ & -0.24 & & 0.46 & 0.23 & 0.17 & 001 & 017 & 025 & 0.28 & & & 030 & 0.35 & 0.06 & 0.13 & -0.28 & -0.23 \\
\hline 13 & 1973. & -0.40 & 040 & 0.34 & 0.30 & 0.25 & 0.09 & 000 & 0.31 & 0.17 & 26 & $11+2>$ & 37 & 0.31 & 0.05 & .17 & -0.19 & -0.17 \\
\hline 14 & $1974-1993$ & -0.43 & & 0.26 & 0.28 & 0.19 & 0.05 & -0.13 & 0.28 & 0.08 & .23 & 0.14 & 0.43 & 0.26 & -0.13 & .09 & -0.25 & -0.03 \\
\hline 15 & 1975 - 1994 & 0.40 & .23 & & & & & -0.18 & 0.15 & & & 0.06 & 0.45 & 0.23 & -0.20 & -0.01 & -0.35 & 0.05 \\
\hline 16 & $1976-1995$ & -0.34 & 0.5 & 026 & 0.32 & -0.02 & 012 & -0.09 & 0.31 & & 0.28 & & 0.58 & 0.32 & -0.19 & 0.12 & 02 & 0.02 \\
\hline 17 & 1977 - 1996 & 0.35 & & & 0.28 & 0.00 & & -0.10 & & 0.03 & & & 0.59 & 0.32 & -0.18 & .11 & -0.29 & 0.02 \\
\hline 18 & 1978 - 1997 & -0.17 & 040 & 0.10 & 0.40 & -0.13 & -0.06 & 0.07 & 0.23 & -0.12 & 0.16 & 0.33 & 0.61 & 0.26 & -0.12 & 0.15 & -0.20 & -0.03 \\
\hline 19 & $1979-1998$ & 0.14 & & & 0.34 & -0.05 & -0.08 & 0.05 & 0.22 & -0.12 & .18 & & 0.59 & 0.20 & -0.19 & .08 & -0.25 & -0.04 \\
\hline 20 & $1980-1999$ & -0.01 & 0 & 0.09 & 0.42 & -0.02 & -0.25 & -0.08 & 0.37 & -0.17 & 0.15 & & 0.48 & 0.17 & -0.02 & 0.03 & -0.20 & -0.04 \\
\hline 21 & $1981-$ & 0.03 & & & 0.27 & -0.05 & -0.25 & 0.03 & 0.37 & -0.15 & 0.13 & & 0.36 & .12 & 0.03 & -0.11 & -0.19 & -0.12 \\
\hline 22 & $1982-2001$ & -0.11 & 30 & 0.03 & 0.26 & -0.15 & -0.34 & -0.07 & 0.37 & -0.15 & .13 & & 31 & 25 & .03 & -0.16 & -0.09 & -0.22 \\
\hline 23 & $1983-2002$ & & & & & & & & 0.35 & & 0.20 & & & 032 & 007 & -0.11 & & -0.27 \\
\hline 24 & $1984-2003$ & .23 & & .02 & 0.26 & 0.11 & -0.46 & -0.29 & .32 & .03 & .16 & & .34 & 0.32 & .03 & -0.10 & & -0.26 \\
\hline 25 & $1985-2004$ & & & & & & & -0.28 & & & & & & 0.29 & -0.09 & -0.05 & & -0.26 \\
\hline 26 & $1986-2005$ & 0.18 & & & 0.21 & & -0.58 & -0.27 & & 0.08 & & & 0.47 & 0.19 & -0.08 & -0.03 & -0.08 & 0.28 \\
\hline 27 & $1987-2006$ & ( & & & & & & -0.37 & & & & & & 0.21 & & 0.00 & & -0.29 \\
\hline 28 & 1988 & 0.09 & & & & & -0.39 & -0.27 & & & .02 & & & 31 & .06 & 0.14 & -0.03 & -0.27 \\
\hline 29 & $1989-2008$ & 0.09 & & -0.11 & 0.09 & 0.01 & -0.48 & -0.24 & 0.39 & 0.15 & 0.11 & 0.10 & 0.34 & 0.44 & -0.04 & -0.16 & -0.12 & -0.21 \\
\hline 30 & $1990-2009$ & 0.10 & & & & & & -0.25 & & & & & & & -0.03 & -0.17 & & \\
\hline 31 & $1-2010$ & 0.05 & & -0.15 & 0.1 & 0.04 & -0.57 & -0.28 & & 6 & 4 & & 0.30 & 0.40 & -0.10 & -0.21 & -0.07 & -0.08 \\
\hline 32 & $1992-2011$ & -0.06 & & & & -0.05 & -0.38 & & & -0.06 & & & & 0.40 & & -0.09 & & -0.14 \\
\hline 33 & 1993 & 0.00 & 31 & .29 & 0.28 & 0.05 & -0.42 & -0.36 & 0.28 & -0.21 & .17 & & 0.38 & 0.45 & -0.11 & -0.06 & 0.16 & -0.12 \\
\hline 34 & $1994-2013$ & -0.09 & & & 0.21 & -0.01 & & & & & & & & 0.40 & -0.08 & & 0.19 & -0.21 \\
\hline 35 & $1995-2014$ & -0.08 & 40 & & 0.24 & 0.02 & -0.54 & -0.11 & 0.44 & -0.16 & & & & 0.37 & .02 & -0.05 & 0.25 & -0.31 \\
\hline 36 & $1996-2015$ & -0.15 & 0.33 & -0.15 & 0.22 & 0.02 & -0.58 & -0.15 & 0.40 & -0.18 & 0.34 & 0.26 & 0.23 & 0.37 & -0.04 & -0.12 & 020 & -0.26 \\
\hline 37 & $1997-2016$ & -0.11 & (3) & -0.10 & 0.26 & -0.03 & -0.58 & -0.11 & 0.39 & -0.10 & 0.42 & 0.29 & 0.19 & 0.38 & -0.01 & -0.13 & 0.38 & -0.25 \\
\hline 38 & $1998-2017$ & -0.25 & 0.23 & -0.20 & 0.09 & -0.11 & -0.59 & -0.22 & & -0.02 & & & & 0.44 & -0.21 & -0.01 & 0.31 & -0.34 \\
\hline 39 & $1999-2018$ & -0.23 & 0.12 & -0.10 & 0.02 & -0.17 & -0.55 & -0.19 & 0.18 & 0.08 & 0.49 & -0.04 & 0.11 & 0.42 & -0.23 & -0.12 & 0.29 & -0.37 \\
\hline
\end{tabular}

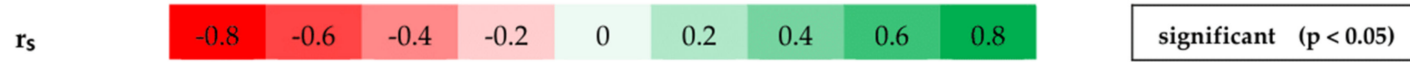

Figure A2. Running Spearman correlations between RWI chronology and timelines of temperature variables at Osobitá. 


\begin{tabular}{|c|c|c|c|c|c|c|c|c|c|c|c|c|c|c|c|c|c|c|}
\hline & terval & PY & PY & XGS & PGS & P10 & PP11 & PP12 & PM1 & PM2 & PM3 & PM4 & PM5 & PM6 & PM7 & PM8 & PM9 & PM10 \\
\hline 1 & $1961-1980$ & & -0.03 & 0.10 & -0.33 & & & & 0.39 & 0.14 & 0.10 & -0.27 & -0.39 & 0.03 & -0.18 & 0.08 & 0.38 & -0.17 \\
\hline 2 & 1962 - 1981 & 0.00 & -0.15 & 03 & -0.39 & 0.15 & 0.27 & 0.05 & 041 & 0.07 & 0.18 & -0.24 & -0.52 & 0.02 & -0.25 & 0.14 & 0.43 & -0.30 \\
\hline 3 & 1963 - & .07 & -0.29 & 0.14 & 0.38 & 0.06 & 0.19 & 0.08 & 0.46 & -0.02 & 0.04 & -0.25 & -0.59 & 0.17 & -0.26 & .23 & 0.36 & -0.36 \\
\hline 4 & $1964-1983$ & -0.12 & -0.32 & 0.12 & -0.45 & 0.06 & 0.06 & 0.11 & 0.50 & 0.04 & -0.03 & -0.21 & -0.58 & 0.14 & -0.30 & 0.09 & 0.40 & -0.38 \\
\hline 5 & 1965 - & 21 & .30 & .01 & -0.39 & 0.03 & 0.05 & -0.05 & 0.36 & 0.05 & 0.02 & -0.17 & -0.40 & -0.08 & -0.38 & 0.06 & .47 & -0.27 \\
\hline 6 & $1966-1985$ & -0.21 & -0.22 & 0.02 & -0.34 & 0.08 & 0.00 & -0.03 & 0.37 & 0.03 & 0.05 & -0.09 & -0.33 & -0.04 & -0.34 & 0.08 & 0.38 & -0.34 \\
\hline 7 & $1967-1986$ & -0.01 & -0.22 & 0.16 & -0.32 & -0.10 & 0.16 & 0.11 & 0.33 & 0.16 & -0.09 & -0.06 & -0.26 & 0.03 & -0.34 & 0.28 & 0.19 & -0.26 \\
\hline 8 & $1968-1987$ & -0.01 & -0.12 & 0.23 & -0.28 & -0.08 & 0.14 & 0.22 & 0.41 & 0.23 & -0.11 & -0.05 & -0.09 & 0.02 & -0.26 & 0.25 & 0.18 & -0.29 \\
\hline 9 & $1969-1988$ & -0.07 & -0.10 & 0.22 & -0.17 & 0.02 & 010 & 0.08 & 0.40 & 0.20 & -0.19 & 0.06 & 0.02 & 0.08 & -0.20 & 0.07 & 0.11 & -0.27 \\
\hline 10 & $1970-1989$ & -0.07 & -0.17 & 0.17 & -0.18 & 0.01 & 0.12 & 0.08 & 0.33 & 0.19 & -0.21 & 0.10 & 0.03 & 0.04 & -0.21 & 0.04 & 0.12 & -0.25 \\
\hline 11 & 1971 - 1990 & 0.13 & -0.03 & 0.31 & -0.10 & -0.06 & 0.20 & 0.19 & 0.32 & 0.32 & -0.13 & 0.11 & -0.03 & -0.02 & -0.04 & 0.21 & -0.04 & -0.18 \\
\hline 12 & 1972 - 1991 & 0.05 & -0.09 & 0.27 & -0.14 & 0.02 & 0.27 & 0.19 & 0.17 & 0.20 & -0.10 & 0.08 & 0.06 & 0.02 & -0.01 & 0.04 & -0.03 & -0.25 \\
\hline 13 & $1973-1992$ & 0.00 & -0.01 & 0.17 & 0.03 & -0.03 & 0.24 & 0.12 & 0.23 & 0.20 & -0.25 & 0.20 & 0.23 & -0.09 & 0.13 & 0.20 & -0.07 & -0.31 \\
\hline 14 & $1974-1993$ & -0.05 & -0.01 & 0.19 & 0.03 & -0.07 & 021 & 0.16 & 0.21 & 0.21 & -0.22 & 0.20 & 0.33 & -0.08 & 0.10 & 0.18 & -0.13 & -0.33 \\
\hline 15 & 1975 - 1994 & -0.06 & -0.04 & 0.11 & -0.06 & -0.22 & 0.15 & -0.01 & 0.23 & 0.31 & -0.27 & 0.05 & 0.17 & 0.00 & 0.20 & 0.16 & -0.12 & -0.38 \\
\hline 16 & 1976 - 1995 & -0.03 & -0.11 & 011 & -0.06 & -0.22 & 0.13 & 0.16 & 0.22 & 0.19 & -0.31 & -0.14 & 0.16 & 0.02 & 0.38 & 0.06 & -0.31 & -0.20 \\
\hline 17 & $1977-1996$ & 0.05 & -0.06 & 0.09 & -0.06 & -0.21 & & 0.11 & 0.30 & 0.15 & -0.42 & -0.05 & 0.20 & -0.01 & 0.38 & 0.06 & -0.20 & -0.17 \\
\hline 18 & $1978-1997$ & 0.15 & 0.02 & -0.10 & 0.09 & -0.21 & -0.04 & 0.09 & 015 & -0.02 & -0.46 & -0.07 & 0.21 & 010 & 0.44 & -0.06 & -028 & -0.14 \\
\hline 19 & $1979-1998$ & 0.16 & -0.08 & -0.31 & 0.10 & -0.35 & 0.01 & -0.10 & 0.02 & -0.12 & -0.47 & 0.01 & 0.17 & -0.03 & 0.42 & -0.13 & -0.15 & 0.02 \\
\hline 20 & 1980 - 1999 & 0.11 & -0.11 & -0.35 & 0.06 & -0.43 & 0.02 & -0.07 & 0.07 & -0.20 & -0.40 & -0.09 & 0.15 & -0.07 & 0.35 & -0.16 & -0.06 & 0.10 \\
\hline 21 & $1981-2000$ & 0.14 & -0.16 & -0.25 & -0.09 & -0.47 & & -0.06 & 0.17 & -0.19 & -0.27 & -0.08 & 0.03 & -0.20 & 0.42 & -0.18 & -0.09 & 0.09 \\
\hline 22 & $1982-2001$ & 0.17 & -0.04 & -0.19 & -0.05 & -0.40 & 0.01 & -0.13 & 0.24 & -0.14 & -0.29 & -0.15 & 0.14 & -0.04 & 0.25 & -0.14 & -0.15 & .26 \\
\hline 23 & $1983-2002$ & 0.17 & -0.10 & -0.14 & -0.11 & -0.29 & 0.03 & -0.11 & 0.27 & -0.15 & -0.34 & -0.21 & 0.16 & 0.02 & 0.18 & -0.22 & -0.22 & 0.23 \\
\hline 24 & $1984-2003$ & 0.21 & -0.13 & -0.16 & -0.14 & -0.23 & & -0.14 & 0.28 & -0.20 & -0.32 & -0.22 & 0.15 & -0.01 & 0.23 & -0.24 & -0.25 & 0.21 \\
\hline 25 & 1985 - 2004 & 0.37 & -0.11 & -0.18 & -0.06 & -0.26 & 0.18 & -0.02 & 0.20 & -0.32 & -0.41 & -0.21 & 0.15 & -0.05 & 0.30 & -0.09 & -0.25 & 0.16 \\
\hline 26 & $1986-2005$ & 0.36 & & & -0.09 & -0.28 & & & & -0.39 & -0.25 & -0.29 & 0.15 & 0.06 & 0.18 & -0.20 & -0.18 & 0.26 \\
\hline 27 & $1987-2006$ & 0.33 & -0.08 & -0.20 & -0.03 & -0.24 & 0.04 & 0.10 & 0.15 & -0.43 & -0.21 & -0.19 & 0.18 & 0.05 & 0.20 & -0.22 & -0.19 & 0.27 \\
\hline 28 & $1988-2007$ & & -0.13 & & 0.00 & -0.28 & & & & -0.48 & -0.20 & & & 0.02 & 0.14 & -0.21 & & 0.28 \\
\hline 29 & $1989-2008$ & 0.53 & -0.14 & -0.19 & -0.04 & -0.26 & 0 & 16 & 15 & -0.45 & -0.16 & -0.24 & 0.15 & -0.05 & 0.08 & -0.18 & -0.10 & 0.20 \\
\hline 30 & $1990-2009$ & 0.52 & -0.15 & -0.18 & -0.05 & -0.27 & 0.18 & 0.16 & 0.14 & -0.47 & -0.16 & -0.23 & 0.12 & -0.04 & 0.05 & -0.20 & -0.09 & 0.19 \\
\hline 31 & $1991-2010$ & 0.51 & -0.15 & -0.24 & -0.02 & -0.29 & & & 0.13 & -0.45 & -0.21 & & 0.14 & -0.11 & 0.03 & -0.20 & -0.04 & 0.20 \\
\hline 32 & $1992-2011$ & 0.68 & -0.06 & -0.18 & 0.11 & -0.39 & 0.24 & 0.10 & 0.28 & -0.41 & -0.20 & -0.06 & 0.09 & -0.08 & 0.07 & -0.11 & -0.08 & 0.23 \\
\hline 33 & $1993-2012$ & 0.65 & -0.16 & -0.24 & 0.02 & -0.32 & & -0.01 & 0.33 & -0.38 & -0.27 & -0.15 & 0.04 & -0.11 & 0.05 & -0.24 & -0.13 & 0.31 \\
\hline 34 & $1994-2013$ & 0.65 & -0.16 & -0.23 & 0.02 & -0.31 & & 0.01 & 0.32 & -0.38 & -0.24 & -0.15 & 0.04 & -0.14 & 0.06 & -0.24 & -0.11 & 0.34 \\
\hline 35 & $1995-2014$ & 0.52 & -0.28 & -0.09 & -0.03 & -0.21 & 0.10 & 0.19 & 0.40 & -0.49 & -0.17 & -0.15 & 0.06 & -0.14 & 0.02 & -0.31 & -0.17 & 0.45 \\
\hline 36 & $1996-2015$ & 0.47 & -0.27 & 00 & -0.04 & -0.17 & & 0.21 & 0.4 & -0.45 & -0.17 & -0.16 & 0.07 & -0.18 & -0.08 & -0.33 & -0.10 & 0.44 \\
\hline 37 & $1997-2016$ & 0.52 & -0.32 & -0.07 & -0.08 & -0.20 & 0.13 & 0.21 & 0.38 & -0.49 & -0.09 & -0.28 & -0.02 & -0.18 & -0.12 & -0.25 & -0.03 & 0.39 \\
\hline 38 & $1998-2017$ & 0.49 & -0.28 & 0.02 & -0.12 & -0.20 & 0.2 & 0.29 & 0.45 & -0.43 & -0.07 & -0.30 & -0.02 & -0.17 & -0.25 & -0.11 & 0.00 & 0.44 \\
\hline 39 & $1999-2018$ & 0.56 & -0.30 & 08 & -0.29 & -0.15 & 0.07 & 0.25 & 0.57 & -0.30 & -0.02 & -0.31 & 0.01 & -0.19 & -0.27 & -0.02 & -0.17 & 0.39 \\
\hline
\end{tabular}
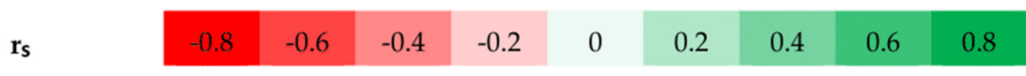

significant $(\mathrm{p}<0.05)$

Figure A3. Running Spearman correlations between RWI chronology and timelines of precipitation variables at Biely kríž. 


\begin{tabular}{|c|c|c|c|c|c|c|c|c|c|c|c|c|c|c|c|c|c|c|}
\hline & terval & PY & Y & XGS & PGS & P10 & PP11 & PP12 & PM1 & PM2 & PM3 & PM4 & PM5 & PM6 & PM7 & PM8 & PM9 & PM10 \\
\hline 1 & $1961-1980$ & & -0.13 & 0.01 & -0.17 & & & & 0.01 & 0.04 & -0.14 & 0.10 & -0.08 & -0.31 & 0.18 & 0.12 & -0.20 & 010 \\
\hline 2 & $1962-1981$ & -0.17 & & 0.00 & & -0.42 & .32 & -0.22 & 0.03 & 0.04 & -0.17 & 0.11 & -0.09 & -0.27 & 0.16 & 0.14 & -0.16 & -0.20 \\
\hline 3 & 1963 - 1982 & -0.21 & 0.07 & 0.09 & -0.13 & -0.44 & -0.32 & -0.24 & 0.04 & 0.11 & -0.11 & 0.14 & -0.06 & -0.25 & 0.14 & 0.14 & -0.15 & -0.21 \\
\hline 4 & $1964-1983$ & -0.24 & -0.10 & 0.13 & & -0.48 & -0.32 & -0.14 & 0.11 & 0.12 & -0.03 & 0.14 & -0.12 & -0.26 & 0.09 & 0.09 & -0.13 & -0.21 \\
\hline 5 & 1965 - 1984 & -0.22 & -0.01 & 0.18 & -0.11 & -0.47 & -0.20 & -0.06 & 0.03 & 0.18 & -0.02 & 0.22 & -0.15 & -0.32 & 0.14 & 0.17 & -0.20 & -0.15 \\
\hline 6 & $1966-1985$ & -0.18 & 0.04 & 0.24 & -0.04 & -0.38 & -0.03 & -0.10 & 0.11 & 0.20 & -0.03 & 0.21 & -0.08 & -0.26 & 0.17 & 0.19 & -0.06 & -0.34 \\
\hline 7 & $1967-1986$ & -0.25 & & 0.16 & -0.13 & -0.27 & -0.02 & -0.02 & 0.19 & 0.03 & .16 & 0.06 & -0.18 & -0.24 & 0.08 & 0.16 & -0.01 & -0.35 \\
\hline 8 & $1968-1987$ & -0.08 & -0.08 & 0.26 & -0.20 & -0.18 & 0.15 & -0.05 & 0.19 & 0.08 & -0.10 & 0.12 & -0.28 & -0.24 & 0.08 & 0.19 & -0.14 & -0.22 \\
\hline 9 & $1969-1988$ & -0.09 & -0.12 & 0.28 & -0.27 & -0.22 & 0.19 & -0.03 & 0.12 & 0.16 & 0.02 & 0.05 & -0.29 & -0.18 & 0.02 & 0.15 & -0.17 & -0.29 \\
\hline 10 & $1970-1989$ & -0.08 & -0.09 & 0.29 & -0.21 & -0.22 & 0.20 & -0.01 & 0.13 & 0.16 & 0.07 & 0.11 & -0.26 & -0.16 & 0.01 & 0.13 & -0.13 & -0.29 \\
\hline 11 & $1971-1990$ & 0.02 & -0.20 & 0.25 & -0.30 & -0.22 & 0.18 & 0.05 & 0.10 & 0.14 & 0.10 & 0.04 & -0.27 & -0.15 & -0.08 & 0.08 & -0.05 & -0.39 \\
\hline 12 & 1972 - 1991 & 0.06 & -0.28 & 0.27 & -0.38 & 0.19 & & 0.09 & 0.10 & 14 & 13 & 0.03 & -0.27 & -0.15 & -0.17 & 0.01 & -0.07 & -0.41 \\
\hline 13 & $1973-1992$ & 0.24 & -0.38 & 0.50 & -0.61 & -0.15 & 0.14 & 009 & 0.25 & 0.31 & 0.33 & -0.10 & -0.47 & -0.19 & -0.16 & -0.21 & -0.07 & -0.34 \\
\hline 14 & $1974-1993$ & 0.14 & -0.40 & 0.46 & -0.63 & -0.03 & 0.15 & 0.14 & 0.26 & 0.31 & 0.37 & -0.15 & -0.50 & -0.26 & -0.15 & -0.16 & -0.10 & -0.35 \\
\hline 15 & $1975-1994$ & 0.23 & -0.42 & 0.39 & -0.65 & 0.02 & 0.24 & 0.15 & 0.15 & 0.32 & 0.24 & -0.21 & -0.51 & -0.27 & 0.01 & -0.08 & -0.09 & -0.41 \\
\hline 16 & $1976-1995$ & 0.40 & -0.42 & 0.38 & -0.67 & 0.15 & 0.19 & 0.27 & 0.10 & 0.34 & 0.25 & -0.18 & -0.57 & -0.19 & 0.11 & -0.08 & -0.19 & -0.34 \\
\hline 17 & 1977 - 1996 & 0.39 & -0.42 & 0.39 & -0.63 & 0.12 & 0.18 & 0.23 & 0.12 & 0.30 & 0.20 & -0.22 & -0.55 & -0.27 & 0.15 & -0.09 & -0.14 & -0.36 \\
\hline 18 & $1978-1997$ & 0.26 & 044 & & -0.58 & 0.21 & & .27 & 018 & 0.16 & 0.11 & -0.35 & -0.49 & -0.09 & 0.06 & -0.12 & -0.02 & -0.31 \\
\hline 19 & $1979-1998$ & 0.17 & -0.48 & 0.26 & -0.59 & 0.14 & 0.28 & 0.28 & 0.14 & 0.12 & .11 & -0.34 & -0.47 & -0.08 & -0.07 & -0.07 & 0.01 & -0.30 \\
\hline 20 & $1980-1999$ & 0.27 & -0.42 & & -0.45 & 0.16 & & & $0 \cap 7$ & 0.35 & -0.08 & -0.22 & -0.47 & 0.07 & & -0.15 & -0.13 & -0.11 \\
\hline 21 & $1981-2000$ & 0.22 & 0.40 & 0.06 & -0.37 & 0.07 & 0.54 & 0.39 & -0.10 & 0.24 & -0.15 & -0.23 & -0.51 & 0.14 & 0.04 & -0.05 & -0.12 & 0.03 \\
\hline 22 & $1982-2001$ & 0.19 & -0.46 & 0.00 & -0.46 & 0.15 & 0.46 & 0.36 & -0.11 & 0.20 & -0.14 & -0.30 & -0.45 & 0.03 & -0.03 & -0.02 & -0.22 & 0.14 \\
\hline 23 & $1983-2002$ & 0.30 & -0.37 & -0.03 & -0.35 & 0.07 & 0.53 & 0.36 & -0.14 & 0.24 & -0.16 & -0.37 & -0.39 & 0.08 & 0.09 & 0.01 & -0.23 & 0.26 \\
\hline 24 & $1984-2003$ & 0.38 & -0.33 & -0.11 & -0.34 & 0.11 & 0.57 & 0.30 & -0.25 & 0.24 & -0.23 & -0.34 & -0.31 & -0.01 & 0.09 & 0.05 & -0.22 & 0.22 \\
\hline 25 & $1985-2004$ & 0.41 & (1.47 & & & 0.19 & & & -0.21 & 0.04 & & & -0.32 & -0.03 & & -0.02 & -0.05 & 0.25 \\
\hline 26 & $1986-2005$ & 0.38 & -0.40 & -0.21 & -0.38 & 0.14 & 0.53 & 0.04 & -0.18 & 0.12 & -0.30 & -0.35 & -0.36 & 0.04 & -0.12 & 0.07 & -0.15 & 0.22 \\
\hline 27 & $1987-2006$ & 0.27 & -0.30 & -0.14 & -0.32 & 0.13 & 0.57 & -0.09 & -0.22 & 0.26 & -0.24 & -0.23 & -0.42 & 0.01 & -0.09 & 0.06 & 0.00 & 0.25 \\
\hline 28 & $1988-2007$ & 0.09 & -0.30 & -0.03 & 0.32 & 0.05 & 0.53 & -0.01 & -0.03 & 0.18 & -0.18 & -0.41 & -0.37 & -0.06 & -0.22 & 0.07 & 0.14 & 0.22 \\
\hline 29 & $1989-2008$ & 0.26 & -0.25 & -0.05 & -0.27 & 0.17 & 0.58 & -0.16 & -0.03 & 0.01 & -0.10 & -0.37 & -0.37 & -0.19 & -0.11 & -0.04 & 0.10 & 0.32 \\
\hline 30 & $1990-2009$ & 0.26 & -0.24 & -0.10 & -0.26 & 0.19 & 0.58 & -0.17 & -0.03 & -0.02 & -0.11 & -0.32 & -0.39 & -0.19 & & -0.04 & 0.12 & 0.29 \\
\hline 31 & $1991-2010$ & 0.23 & -0.31 & -0.04 & -0.31 & 0.11 & 0.50 & -0.19 & -0.08 & -0.02 & 0.02 & -0.42 & -0.42 & -0.18 & -0.17 & -0.01 & 0.05 & 0.30 \\
\hline 32 & 1992 - 2011 & 0.35 & .42 & -0.23 & $-0.3 /$ & -0.05 & 0.61 & -0.08 & -0.26 & -0.18 & -0.02 & -0.47 & -0.36 & -0.15 & -0.08 & -0.06 & -0.09 & 0.22 \\
\hline 33 & $1993-2012$ & 0.27 & -0.45 & -0.34 & -0.42 & -0.15 & 0.44 & -0.03 & -0.26 & -0.34 & -0.14 & -0.45 & -0.40 & -0.11 & -0.02 & -0.10 & -0.16 & 0.23 \\
\hline 34 & $1994-2013$ & 0.41 & -0.35 & -0.41 & -0.18 & -0.29 & 0.35 & -0.03 & -0.30 & -0.42 & -0.16 & -0.26 & -0.42 & -0.22 & & 0.03 & -0.04 & 0.27 \\
\hline 35 & 1995 - 2014 & 0.32 & -0.43 & -0.38 & -0.25 & -0.33 & 0.27 & -0.03 & -0.26 & -0.49 & -0.08 & -0.20 & -0.41 & -0.27 & 0.01 & 0.05 & 0.01 & 0.34 \\
\hline 36 & $1996-2015$ & 0.34 & -0.34 & -0.37 & -0.18 & -0.32 & 0.31 & 0.03 & -0.29 & -0.44 & -0.03 & -0.13 & -0.39 & -0.18 & 0.06 & 0.08 & 0.01 & 0.34 \\
\hline 37 & $1997-2016$ & 0.31 & -0.36 & -0.32 & -0.19 & -0.28 & 0.31 & 0.00 & -0.31 & -0.35 & -0.05 & -0.11 & -0.45 & -0.21 & 0.07 & 0.07 & -0.07 & 0.38 \\
\hline 38 & $1998-2017$ & 0.22 & -0.33 & -0.49 & -0.08 & -0.21 & 0.21 & -0.16 & $\mid-0.49$ & $\mid-0.38$ & -0.16 & 0.05 & -0.29 & -032 & 0.14 & 0.08 & -0.01 & 0.36 \\
\hline 39 & $1999-2018$ & 0.26 & -0.21 & -0.50 & 0.05 & -0.17 & 0.21 & -0.16 & $|-0.45|$ & $\mid-0.40$ & -0.19 & 0.14 & -0.18 & -0.36 & 0.21 & 0.09 & 0.06 & 0.39 \\
\hline
\end{tabular}

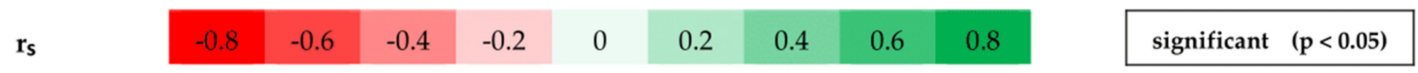

Figure A4. Running Spearman correlations between RWI chronology and timelines of precipitation variables at Osobitá. 


\section{References}

1. Š̌kvarenina, J.; Vido, J.; Mind'aš, J.; Střelcová, K.; Škvareninová, J.; Flesicher, P.; Bošel'a, M. Globálne Zmeny Klímy a Lesné Ekosystémy; Technical University in Zvolen: Zvolen, Slovakia, 2018; 210p.

2. Jakuš, R.; Blaženec, M.; Gurtsev, A.; Holuša, J.; Hroššo, B.; Křenova, Z.; Longauerová, V.; Lukášová, K.; Majdák, A.; Mezei, P.; et al. Princípy Ochrany Dospelých Smrekových Porastov Pred Podkôrnym Hmyzom; Department of Forest Ecology of Slovak Academy of Science: Zvolen, Slovakia, 2015; 152p.

3. Fritts, H.C. Tree Rings and Climate; Academic Press: London, UK, 1976; 567p.

4. Kyncl, J. Letokruhy Jako Kalendár̆ I Záznamnik; Grada: Praha, Czech Republic, 2016; 144p.

5. Treml, V.; Ponocná, T.; Büntgen, U. Growth trends and temperature responses of treeline Norway spruce in the Czech-Polish Sudetes Mountains. Clim. Res. 2012, 55, 91-103. [CrossRef]

6. Ponocná, T.; Chuman, T.; Rydval, M.; Urban, G.; Migala, K.; Treml, V. Deviations of treeline Norway spruce radial growth from summer temperatures in East-Central Europe. Agric. For. Meteorol. 2018, 253, 62-70. [CrossRef]

7. Vitali, V.; Büntgen, U.; Jürgen, B. Seasonality matters-The effects of past and projected seasonal climate change on the growth of native and exotic conifer species in Central Europe. Dendrochronologia 2018, 48, 1-9. [CrossRef]

8. Cienciala, E.; Altman, J.; Doležal, J.; Kopáček, J.; Štěpánek, P.; Ståhl, G.; Tumajer, J. Increased spruce tree growth in Central Europe since 1960s. Sci. Total Environ. 2018, 619, 1637-1647. [CrossRef]

9. Altman, J.; Fibich, P.; Šantrůčková, H.; Doležal, J.; Štěpánek, P.; Kopáček, J.; Hůnová, I.; Oulehle, F.; Tumajer, J.; Cienciala, E. Environmental factors exert strong control over the climate-growth relationships of Picea abies in Central Europe. Sci. Total Environ. 2017, 609, 506-516. [CrossRef] [PubMed]

10. Sedmáková, D.; Sedmák, R.; Bošel’a, M.; Ježík, M.; Blaženec, M.; Hlásny, T.; Marušák, R. Growth-climate responses indicate shifts in the competitive ability of European beech and Norway spruce under recent climate warming in East-Central Europe. Dendrochronologia 2019, 54, 37-48. [CrossRef]

11. Bošel'a, M.; Sedmák, R.; Sedmáková, D. Vplyv Zmien Prostredia na Dynamiku Radiálneho Rastu Jedle a Smreka v Západných Karpatoch: Konzekvencie pre Strategické Rozhodovanie, Dendrofórum 2014 Aktuální Dendrochronologický Výzkum, Prague, Czech Republic, 20-21 November 2014; Faculty of the Natural Sciences, Charles University: Prague, Czech Republic, 2014.

12. Parobeková, Z.; Sedmáková, D.; Kucbel, S.; Pittner, J.; Jaloviar, P.; Saniga, M.; Balanda, M.; Vencurik, J. Influence of disturbances and climate on high-mountain Norway spruce forests in the Low Tatra Mts., Slovakia. For. Ecol. Manag. 2016, 380, 128-138. [CrossRef]

13. Buras, A.; Spyt, B.; Janecka, K.; Kaczka, R. Divergent growth of Norway spruce on Babia Góra Mountain in the western Carpathians. Dendrochronologia 2018, 50, 33-43. [CrossRef]

14. Kaczka, R.; Czajka, B.; Łajczak, A. The Tree Ring Growth Responses to Climate in the Timberline Ecotone of Babia Góra Mountain. Geogr. Pol. 2015, 88, 163-176. [CrossRef]

15. Carrer, M.; Motta, R.; Nola, P. Significant Mean and Extreme Climate Sensitivity of Norway Spruce and Silver Fir at Mid-Elevation Mesic Sites in the Alps. PLoS ONE 2012, 11, e50755. [CrossRef]

16. Ding, H.; Pretzsch, H.; Schütze, G.; Rötzer, T. Size-dependence of tree growth response to drought for Norway spruce and European beech individuals in monospecific and mixed-species stands. Plant Biol. 2017, 5, 709-719. [CrossRef]

17. Eastaugh, C.; Pötzelsberger, E.; Hasenauer, H. Assessing the impacts of climate change and nitrogen deposition on Norway spruce (Picea abies L. Karst) growth in Austria with BIOME-BGC. Tree Physiol. 2011, 3, 262-274. [CrossRef] [PubMed]

18. Hlásny, T.; Sitková, Z. Spruce Forest Decline in the Beskids; National Forest Centre, Forest Research Institute: Zvolen, Slovakia; Czech University of Life Sciences: Prague, Czech Republic; Forestry and Game Management Research Institute: Strnady, Czech Republic, 2010; 182p.

19. Kolář, T.; Čermák, P.; Trnka, M.; Žid, T.; Rybníček, M. Temporal changes in the climate sensitivity of Norway spruce and European beech along an elevation gradient in Central Europe. Agric. For. Meteorol. 2017, 239, 24-33. [CrossRef]

20. Rybníček, M.; Čermák, P.; Žid, T.; Kolář, T. Radial Growth and Health Condition of Norway Spruce (Picea abies (L.) Karst.) Stands in Relation to Climate (Silesian Beskids, Czech Republic). Geochronometria 2010, 36, 9-16. [CrossRef]

21. Savva, Y.; Oleksyn, J.; Reich, P.B.; Tjoelker, M.G.; Vaganov, E.A.; Modrzynski, J. Interannual growth response of Norway spruce to climate along an altitudinal gradient in the Tatra Mountains, Poland. Trees 2006, 20, 735-746. [CrossRef]

22. Sidor, C.G.; Ionel, P.; Vlad, R.; Cherubini, P. Different tree-ring responses of Norway spruce to air temperature across an altitudinal gradient in the Eastern Carpathians (Romania). Trees 2015, 29, 985-997. [CrossRef]

23. Cook, E.R.; Kairiukstis, L.A. Methods of Dendrochronology: Applications in the Environmental Sciences; Springer: Berlin/Heidelberg, Germany, 2008; 394p.

24. Stokes, M.A.; Smiley, T.L. An Introduction to Tree-Ring Dating; University of Chicago Press: Chicago, IL, USA, 1968; 73p.

25. Speer, J.H. Fundamentals of Tree-Ring Research; University of Arizona Press: Tucson, AZ, USA, 2010; 333p.

26. Vienna Institute of Archaeological Science. Time Table. Installation and Instruction Manual, Ver. 2.1; Vienna Institute of Archaeological Science: Vienna, Austria, 2005.

27. Holmes, R. Computer-assisted quality control in tree-ring dating and measurement. Tree Ring Bull. 1983, 43, 69.

28. Cook, E. A Time Series Analysis Approach to Tree-Ring Standardization. Ph.D. Thesis, University of Arizona, Tucson, IL, USA, 1985. 
29. Polanco-Martínez, J.M. RolWinMulCor: An R package for estimating rolling window multiple correlation in ecological time series. Ecol. Inform. 2020, 60, 101163. [CrossRef]

30. Hartl-Meier, C.; Zang, C.; Dittmar, C.; Esper, J.; Göttlein, A.; Rothe, A. Vulnerability of Norway spruce to climate change in mountain forests of the European Alps. Clim. Res. 2014, 60, 119-132. [CrossRef]

31. Shelford, V.E. Some concepts of bioecology. Ecology 1931, 3, 455-467. [CrossRef]

32. Putalová, T.; Vacek, Z.; Vacek, S.; Štefančík, I.; Bulušek, D.; Král, J. Tree-ring widths as an indicator of air pollution stress and climate conditions in different Norway spruce forest stands in the Krkonoše Mts. Cent. Eur. For. J. 2019, 65, 21-33.

33. Park Williams, A.; Allen, C.D.; Macalady, C.D.; Griffin, D.; Woodhouse, C.A.; Meko, D.M.; Swetnam, T.W.; Rauscher, S.A.; Seager, R.; Grissino-Mayer, H.D.; et al. Temperature as a potent driver of regional forest drought stress and tree mortality. Nat. Clim. Chang. 2012, 3, 292. [CrossRef]

34. Čejková, A.; Kolár̆, T. Extreme radial growth reaction of Norway spruce along an altitudinal gradient in the Šumava Mountains. Geochronometria 2009, 1, 41. [CrossRef]

35. Juráň, S.; Grace, J.; Urban, O. Temporal Changes in Ozone Concentrations and Their Impact on Vegetation. Atmosphere 2021, 12, 82. [CrossRef]

36. Zapletal, M.; Juráň, S.; Krpeš, V.; Michna, K.; Edwards-Jonášová, M.; Cudlín, P. Effect of Ozone Flux on Selected Structural and Antioxidant Characteristics of a Mountain Norway Spruce Forest. Balt. For. 2018, 24, 261-267. 